NBER WORKING PAPER SERIES

\title{
JUNIOR CAN'T BORROW: A NEW \\ PERSPECTIVE ON THE EQUITY \\ PREMIUM PUZZLE
}

\author{
George M. Constantinides \\ John B. Donaldson \\ Rajnish Mehra
}

Working Paper 6617

http://www.nber.org/papers/w6617

\section{NATIONAL BUREAU OF ECONOMIC RESEARCH 1050 Massachusetts Avenue \\ Cambridge, MA 02138 \\ June 1998}

We thank Andrew Abel, John Cochrane, Roger Craine, Domenico Cucco, Steven Davis, John Heaton, Ming Huang, Thore Johnsen, Hayne Leland, Robert Lucas, Robert McDonald, Merton Miller, Kevin Murphy, Nacy Stokey, Jonathan Parker, Edward Prescott, Raaj Sah, Angel Serrat, Raman Uppal, and seminar participants at conferences and seminars for helpful discussions. We also thank Yu-Hua Cho and Yubo Wang for computational assistance. The usual caveat applies. Constantinides acknowledges financial support from the Center for Research in Security Prices, University of Chicago. Mehra acknowledges financial suppoert from the Academic Senate of the University of California. Donaldson acknowledges financial support from the Faculty Research fund of the Graduate School of Business, Columbia University. Any opinions expressed are those of the author and not those of the National Bureau of Economic Research.

(C) 1998 by George M. Constantinides, John B. Donaldson, and Rajnish Mehra. All rights reserved. Short sections of text, not to exceed two paragraphs, may be quoted without explicit permission provided that full credit, including $(\mathcal{C}$ notice, is given to the source. 
Junior Can't Borrow: A New Perspectie on the Equity Premium Puzzle

George M. Constantinides, John B. Donaldson, and Rajnish Mehra

NBER Working Paper No. 6617

June 1998

\begin{abstract}
Ongoing questions on the historical mean and standard deviation of the return on equities and bonds and on the equilibrium demand for these securities are addressed in the context of a stationary, overlapping-generations economy in which consumers are subject to a borrowing constraint. The key feature captured by the OLG economy is that the bulk of the future income of the young agents is derived from their wages forthcoming in their middle age, while the bulk of the future income of the middle-aged agents is derived from their savings in equity and bonds. The young would like to borrow and invest in equity, but the borrowing constraint prevents them from doing so. The middleaged choose to hold a diversified portfolio that includes positive holdings of bonds, and this explains the demand for bonds. Without the borrowing constraint, the young borrow and invest in equity, thereby decreasing the mean equity premium and increasing the rate of interest.
\end{abstract}

George M. Constantinides

Graduate School of Business

The University of Chicago

1101 East 58th Street

Chicago, IL 60637

and NBER

gmc@gsb.uchicago.

Rajnish Mehra

Department of Economics

Univsersity of California, Santa Barbara

2127 North Hall

Santa Barbara, CA 93106-9210
John B. Donaldson

Graduate School of Business

Columbia University

101 Uris Hall

New York, NY 10027 


\section{INTRODUCTION}

This paper addresses four anomalies in the financial markets. Why do so few consumers hold equities and bonds? Conditional on holding financial assets, why do consumers hold bonds, given that equities have outperformed bonds by a substantial margin in this century? Why is the historical premium on equities over bonds so high, given the low covariance of equity returns and per capita consumption growth? Lastly, why is the real rate of interest so low? Financial theory has yet to provide a satisfactory answer to these questions in the context of a single model.

Why are these questions important? First and foremost, financial markets play a central role in the allocation of investment capital and in the sharing of risk. Failure to answer these questions suggests that our understanding of the fundamental process of capital allocation is highly imperfect. Second, the basic economic paradigm employed in analyzing financial markets is closely related to the paradigm employed in the study of business cycles and growth. ' Failure to explain the stylized facts of financial markets calls into question the appropriateness of the related paradigms for the study of macro-economic issues.

We construct an OLG exchange economy in which the representative agent lives for three periods. In the first period, a period of human capital acquisition, the agent receives a relatively low endowment income. In the second period the agent is employed and is subject to large wage income uncertainty. In the third period the agent retires and consumes the assets accumulated in the second period.

We explore the implications of a borrowing constraint by deriving and contrasting the stationary equilibria in two versions of the economy. In the borrowing-constrained version the agents are prohibited from borrowing (and selling equity short). It is well known that human capital alone does not collateralize major loans in modern economies for reasons of moral hazard and adverse selection. The borrowing constraint is a reduced-form summary of these considerations. The borrowing-unconstrained economy differs from the borrowing-constrained one only in that the borrowing constraint is absent. This version is intended to capture the spirit of the widely-cited, complete-markets, representative-agent economy.

The key feature captured by the OLG economy is that the bulk of the future income of the young agents is derived from their wages forthcoming in their middle age, while the future income of the

1 This relation relies on the decentralization results in Donaldson and Mehra (1984) and Prescott and Mehra (1980). 
middle-aged agents is derived from their savings in equity and bonds. As a result of this difference, the young have a different response to the mean equity premium than the middle-aged do.

If the equity premium has low correlation with the wage income that the young expect to recerve in their middle age, then the young would like to borrow and invest in equity. Indeed it turns out that, in the stationary equilibrium of all of our borrowing-constrained economies, the equity premium has low correlation with the wage income the young expect to receive in their middle age. The young would like to borrow and invest in equity but the borrowing constraint prevents them from doing so. By contrast, in the borrowing-unconstrained economy the young borrow and invest in equity, thereby decreasing the mean equity premium and raising the rate of interest. Hence the documented puzzle that borrowingunconstrained models typically have difficulty explaining the high mean equity premium and the low rate of interest.

The foregoing discussion begs a question. If equity is so attractive to the young, who ever invests in bonds? The answer is that the saving middle-aged have had the uncertainty in their future wage income largely resolved. The bulk of their future income is derived from their current savings in equity and bonds. The equity premium is positively correlated with the future income of the middle aged because their income is primarily derived from liquidating a portfolio of equity and bonds. The middleaged choose to hold a diversified portfolio that includes positive holdings of bonds and this explains the demand for bonds.

The intuition behind our results is best understood in terms of the stochastic Euler equations of consumption of the marginal investor in the equity and bond markets,

$$
u_{c}\left(c_{t}\right) q_{t}=\beta E\left[u_{c}\left(c_{t+1}\right)\left(q_{t+1}+d_{t+1}\right)\right]
$$

where $\mathrm{q}_{\mathrm{t}}$ is the current ex dividend price of a security (equity or bond), $\mathrm{q}_{\mathrm{t}+1}$ is the ex dividend price next period, $d_{t+1}$ is the dividend (or coupon) next period and $c_{t}, c_{t+1}$ are the current and the nextperiod consumption of the marginal investor. In the constrained case, the young investor is inframarginal in both the equity and bond markets.

For purposes of illustration, consider the extreme case in which aggregate income is constant over time. In a representative-agent economy, the consumption of the representative agent equals the aggregate income and is constant. Since the representative consumer is the marginal investor in the equity and bond markets, the expected return on equity equals the rate of interest and the equity premium is zero. 
By contrast, in the OLG borrowing-constrained economy the marginal investors in equity and bond markets are the middle-aged investors. Since the wage income of the old is zero and since the old consume by selling their savings in equity and bonds, $c_{t+1}$ is positively correlated with the cum dividend price of equity in period $t+1$. Equity pays off in states of low marginal utility (high consumption) making it unattractive to the middle-aged investors, raising its rate of return and giving rise to the equity premium. The young would like to purchase equity as a hedge against wage income fluctuations because the wage income of the middle-aged and the aggregate dividend are perfectly negatively correlated. However the borrowing constraint prevents them from doing so-they are inframarginal in both the equity and bond markets. If the borrowing constraint is relaxed, the young issue bonds thereby raising the rate of return. The increase in the bond return induces the middle-aged to shift their portfolio holdings in favor of the bond; the increase in the demand for equity by the young and the decrease in the demand for equity by the middle-aged work in opposite directions; on balance, the effect is to increase both the equity and the bond return while simultaneously shrinking the equity premium.

In our calibrated economies the correlation between the aggregate dividend and the wage income of the middle-aged is not -1 , as in the above example, but ranges between high positive and high negative values. In the equilibrium of all of the borrowing-constrained economies it turns out that the correlation between the equity premium and the wage income of the middle-age is close to zero. Whereas equity is no longer a hedge against future wage uncertainty for the young, it is nevertheless attractive to the young because of the large mean equity premium and the low correlation of the premium with the wage income of the middle-aged.

The paper is organized as follows. In the remainder of this section we review the related literature. The economy is defined in Section 2. The stationary equilibrium is defined and characterized in Section 3, with the proof of existence in the borrowing-constrained economy relegated to Appendix A. In Section 4 we discuss the calibration of the economy. In Section 5 we present and discuss the equilibrium results in both the borrowing-constrained and the unconstrained economies for a plausible range of parameter values. Technical aspects of the numerical calculations are relegated to Appendix B. Extensions are discussed in the concluding Section 6.

The observation that, contrary to the predictions of standard economic theory, only a small fraction of individuals and households hold equities either directly or indirectly, was made in Mankiw and Zeldes (1991), Blume and Zeldes (1993), and Haliassos and Bertaut (1995).

The question as to why the historical equity premium is so high and the real rate of interest is so low was first raised in Mehra and Prescott (1985). They demonstrated that the equilibrium of a 
reasonably parameterized, representative-consumer exchange economy is able to furnish a mean annual premium of equity return over the riskless rate of, at most, $0.35 \%$, in contrast to its historical level of $6 \%$ in U.S. data. Furthermore, the equilibrium annual riskless rate of interest is consistently too high, about $4 \%$, as opposed to the observed $1 \%$ in U.S. data. ${ }^{2}$ In tests of the conditional Euler equations of the per capita consumption, Hansen and Singleton (1982), Hansen and Jagannathan (1991), Ferson and Constantinides (1991) and others also rejected the model.

Several generalizations of key features of the Mehra and Prescott (1985) model have been proposed to mitigate its poor performance. These include alternative assumptions on preferences, ${ }^{3}$ modified probability distributions to admit rare but disastrous events, ${ }^{4}$ incomplete markets 5 and market imperfections. ${ }^{6}$ Cochrane and Hansen (1992) and Kocherlakota (1996) provided excellent surveys of this literature.

Equilibrium models that allow for consumer holdings of bonds, consistent with the observed per capita supply of bonds, are difficult to construct. Aiyagari and Gertler (1991) and Heaton and Lucas (1996) presented models with infinitely-lived consumers, incomplete consumption insurance and market frictions which cannot simultaneously generate the consumers' holdings of bonds and the mean equity premium. ${ }^{7}$ In these models the borrowing constraint induces merely an inventory demand for equity and bonds by the infinitely-lived consumers. By contrast, in our model the borrowing constraint plays a very different role on the consumers' life-cycle demand for equity and bonds.

A related puzzle is that a wide variety of partial-equilibrium portfolio models fail to explain why investors who hold financial assets invest in bonds. 8 In these models the equity and bond return

\footnotetext{
2 This point was emphasized by Weil (1989).

3 For example, Abel (1990), Benartzi and Thaler (1995), Boldrin, Christiano and Fisher (1996), Campbell and Cochrane (1995), Constantinides (1990), Daniel and Marshall (1997), Epstein and Zin (1991), and Ferson and Constantinides (1991).

${ }^{4}$ See, Rietz (1988) and Mehra and Prescott (1988).

5For example, Bewley (1982), Constantinides and Duffie (1996), Detemple and Serrat (1996), Lucas (1994), Mankiw (1986), Mehra and Prescott (1985) and Telmer (1993). Heaton and Lucas (1997b) investigated empirically the risk factors and demographic variables that explain cross-sectional differences in portfolio composition and identified the important role of entrepreneurial risk.
}

6For example, Aiyagari and Gertler (1991), Alvarez and Jerman (1997), Basak and Cuoco (1998), Brav and Geczy (1995). Danthine, Donaldson and Mehra (1992), He and Modest (1995), Heaton and Lucas (1996) and Luttmer (1996).

${ }^{7}$ Constantinides and Duffie (1996) pointed out, however, that the above difficulty may be resolved if the consumers' idiosyncratic income shocks are sufficiently persistent and heteroscedastic. Storesletten, Telmer and Yaron (1997) investigated the role of idiosyncratic income shocks in the context of a calibrated OLG model. In their model, whereas the effects of idiosyncratic shocks on the risky returns are substantial, a large fraction of the equity premium remains unexplained.

8 Bertaut and Haliasos (1997), Bodie, Merton and Samuelson (1992), Cocco, Gomes and Maenhout (1997), Gakidis (1997), llaliassos and Hassapis (1997), Jagannathan and Kocherlakota (1996) and Viceira (1997) addressed this issue in models of lifecycle behavior but without market frictions. Heaton and Lucas (1997a) addressed this issue in a model with market frictions but 
processes are given exogenously and reflect the historically large premium of equity over bond returns. The puzzle is distinct from the equity premium puzzle in that the model is not constrained to match features of the per capita consumption process but rather strives to match features of the demand for equity and bonds.

Our paper incorporates standard modeling elements which have been employed extensively in the literature. Specifically, we introduce a borrowing constraint in the context of a stationary, overlapping-generations economy. OLG models abound in the literature. For example, Auerbach and Kotlikoff (1987) employed a deterministic OLG model in their study of fiscal policy. Rios-Rull (1994) employed a stochastic OLG model in his investigation of the role of market incompleteness on equilibrium allocations. The equity premium is a tangential issue in his investigation. When the market is incomplete none of the traded securities may be interpreted as a bond and the equity premium cannot be computed. Unlike these OLG models, our focus is in explaining the demand for and the returns of equity and bonds.

\section{THE ECONOMY}

We consider an overlapping-generations, pure exchange economy. Each generation lives for three periods as young, middle-aged and old. Three is the minimal number of periods that captures the heterogeneity of consumers across age groups which we wish to emphasize: the borrowing-constrained young, the saving middle-aged and the dis-saving old. In the calibration each period is taken to represent twenty years.

Each generation of consumers is modeled by a representative consumer. We recognize that consumer heterogeneity in the form of uninsurable, persistent and heteroscedastic idiosyncratic income shocks has the potential to resolve empirical difficulties encountered by representative-consumer models. ${ }^{9}$ Nevertheless consumer heterogeneity within generations is downplayed in our model in order to isolate and explore the implications of heterogeneity across generations in a parsimonious paradigm. Consumer heterogeneity within a generation, in the form of uninsurable and i.i.d. income shocks is merely invoked in Section 4 in order to allow for a more liberal calibration of the per capita wage income and dividend processes.

There is one consumption good in each period and it perishes at the end of the period. Wages,

without life-cycle behavior.

${ }^{9}$ See, Mehra and Prescott (1985), Mankiw (1986) and Constantinides and Duffie (1996). 
consumption, dividends and coupons as well as the prices of the bond and equity are denominated in units of the consumption good. The consumer born in period $t$ receives deterministic wage income $w^{0}>0$ in period $t$, when young; stochastic wage income $w^{1} t+1>0$ in period $t+1$, when middle-agejd; and zero wage income in period $t+2$, when old. The wage income process of the middle-aged consumer is exogenous, thereby abstracting from the labor-leisure tradeoff. Claims on a consumer's future wage income are not traded.

The stylized assumptions made on the income processes are intended to capture three key aspects of reality in a parsimonious way. 10 First, the wage income received by the young and the old is small compared to the income received by the middle-aged. Therefore the young would like to borrow against future income and the middle-aged would like to save. However the young cannot borrow because of the borrowing constraint. Second, the major future income uncertainty is faced by the young. It turns out that, in the equilibrium of most of our borrowing-constrained economies, the equity premium has low correlation with the wage income that the young expect to receive in their middle age. The young would like to borrow and invest in equity but the borrowing constraint prevents them from doing so. Third, the saving middle-aged face negligible future wage uncertainty. 11 Therefore they save by investing in a portfolio of equities and bonds, driven primarily by the motive of diversification of risk.

The assumption that each period is of length 20 years has the unintended implication that the stochastic income of the middle-aged is perfectly serially correlated over the 20 years. Obviously it is of interest to increase the number of periods within the 60 -year span.

There are only two types of securities in the economy, bonds and equity. Both are infinitely lived. The bond is default-free and pays a fixed coupon $b>0$ in every period in perpetuity. We think of the bond as a proxy for long-term government debt. The supply of the bond is fixed at one unit in perpetuity. 12 Coupon payments are financed out of capital income payments. The ex coupon bond price in period $\mathrm{t}$ is denoted by $\mathrm{q}_{\mathrm{t}}$; it is the price of the claim to the coupon b paid in perpetuity beginning

\footnotetext{
10 The simplifying assumption that the wage income of the young is deterministic and common across the young of the same generation may be relaxed to allow this income to be stochastic and different across the young of the same generation. Whereas this generalization would certainly increase the realism (and complexity) of the model it would not change the basic message of our paper, as long as a sufficiently large fraction of the young were to remain borrowing-constrained.

${ }^{11}$ The simplifying assumption that the wage income of the old is zero may be relaxed to allow for pension income and social security benefits. This income and benefits are deterministic from the perspective of the middle-aged consumers; when incorporated into our analysis, they increase the demand for equity by the middle-aged and reduce the mean equity premium. Specifically, the mean equity premium decreases approximately by the factor $1-x$, where $x$ is the fraction of consumption of the old consumers that is derived from these benefits.

12 It is infeasible to introduce a short-term (say, one-year) bond in this economy because the length of one period is assumed to be 20 years. Although it is feasible to introduce a one-period (20-year) bond in positive net supply, we do not do so for technical reasons. Instead, we report the shadow price of a one-period (20-year) bond in zero net supply.
} 
with period $t+1$.

The consumer born in period $t$ has zero endowment of the bond. This consumer purchases fraction $z_{t, 0}$ of the bond in period $t$, when young; adjusts the bond holding to $z_{t, 1}$ in period $t+1$, when middle-aged; and sells the bond holding in period $t+2$, when old. By convention a negative bond holding denotes a short position in the bond. As we do not explicitly model financial institutions, we assume that the entire supply of the bond is held by the young and middle-aged consumers. Bond market clearing in period $t$ thus requires

$$
\mathrm{z}_{\mathrm{t}, 0}+\mathrm{z}_{\mathrm{t}-1,1} \mathrm{~b}_{1}
$$

The equity is a claim to a dividend stream and pays net dividend $d_{t}$ in period $t$. We think of equity as the sum total of the claims to firms (stocks, corporate bonds, etc.) and real estate. The supply of equity is fixed at one share in perpetuity. The issue and repurchase of equities and bonds is implicitly accounted for by the fact that the equity is defined as the claim to the net dividend. We do not model the process by which firms finance the net dividend-firms are exogenous to the exchange economy. The $e x$ dividend price of equity in period $\mathrm{t}$ is denoted by $\mathrm{q}_{\mathrm{t}} \mathrm{t}$ and is the claim to the dividend stream in perpetuity, beginning with period $\mathrm{t}+1$.

The consumer born in period $t$ also has zero endowment in equity and purchases fraction $z_{t, 0}$ of the equity in period $t$, when young; adjusts the equity holding to $z_{t, 1}$ in period $t+1$, when middle-aged; and sells the equity holding in period $t+2$, when old. As before, a negative equity holding denotes a short position in equity. We assume that the entire supply of equity is held by the young and middle-aged consumers. Stock market clearing in period t requires

$$
\mathrm{z}^{\mathrm{e}} \mathrm{t}_{0}+\mathrm{z}_{\mathrm{t}-1,1}^{\mathrm{e}_{1,1}}=1
$$

The consumer born in period $t$ consumes $c_{t, 0}$ when young, $c_{t, l}$ when middle-aged, and $c_{t, 2}$ when old. The budget constraint of the consumer born in period $t$ is:

$$
c_{t, 0}+z_{t, 0 q} b_{t}+z_{t, 0}^{e_{t}} e_{t} \leq w^{0}
$$

when young;

$$
c_{t, 1}+z_{t, 1}^{b_{t}} b_{t+1}+z_{t, 1}^{e_{t}} e_{t+1} \leq w^{1}{ }_{t+1}+z^{b_{t, 0}}\left(q^{b_{t+1}}+b\right)+z_{t, 0}^{e_{t}}\left(q^{e_{t+1}}+d_{t+1}\right),
$$

when middle-aged; and 


$$
c_{t, 2} \leq z_{t, 1}\left(q^{b_{t+2}}+b\right)+z_{t, 1} e\left(q_{t+2}+d_{t+2}\right)
$$

when old. Old consumers consume their entire wealth since bequests are ruled out in this economy. 13

The consumer born in period $t$ has expected utility

$$
E\left(\sum_{i=0}^{2} \beta^{i} u\left(c_{t, i}\right) \mid \mathfrak{I}_{t}\right)
$$

where $\mathfrak{J}_{t}$ is the information available to the consumer in period t. The subjective discount factor is the constant $\beta$ where $0<\beta<1$. Period utility is of the form

$$
u(c)=(1-\alpha)^{-1}\left(c^{1-\alpha}-1\right)
$$

where $\alpha>0$ is the (constant) relative risk aversion coefficient. We adopt a conventional specification of preferences in order to focus attention on a different issue- the role of the borrowing constraint in the context of an overlapping-generations economy - as well as to make our results directly comparable to the prior literature.

Underlying the economy there is an increasing sequence $\left\{\mathfrak{I}_{t}: t=0,1, \ldots\right\}$ of information sets available to consumers in period $t$. The information set $\mathfrak{I}_{t}$ contains the wage income and dividend histories up to and including period t. It also contains the consumption, bond investment and stock investment histories of all consumers up to and including period $\mathrm{t}-1$. Most of this information turns out to be redundant in the particular stationary equilibria explored in Section 3.

Consumption and investment policies are such that decisions made in period $t$ depend only on information available in period $t$. Formally, a consumption and investment policy of the consumer born in period $t$ is defined as the collection of the $\mathfrak{I}_{t}$-measurable $\left(c_{t, 0}, z_{t, 0}, z_{t, 0}\right)$, the $\mathfrak{I}_{t+1 \text {-measurable }}$

\footnotetext{
${ }^{13}$ The assumption that bequests are ruled out provides a parsimonious way to explore the effect of a borrowing constraint on the consumers' life-cycle bchavior. It is, however, a controversial assumption and merits discussion. Note that what is critical in our model is that the young do not receive (substantial) bequests and, therefore, find the borrowing constraint binding; whether the old derive utility or not from bequeathing wealth to the future generations makes no difference in our model.

A simple way to relax the no-bequest assumption is to interpret the term $\mathrm{c}_{\mathrm{t}, 2}$ as the sum of the old consumers' consumption, $c_{t, 2 c}$, and bequests, $c_{t, 2 b}$; and interpret the term $u\left(c_{t, 2}\right)$ as the old consumers' additive utility function of consumption and bequests. As long as bequests skip a generation and are received by the borrowing-unconstrained middle aged, as it is often the case, the young remain borrowing-constrained and our results remain intact.

More generally we could deline the old consumers' utility of consumption and utility of bequests ("joy of giving") as $v$ ( $c_{t, 2} \mathrm{c}$ ) $+\mathrm{u}\left(\mathrm{c}_{\mathrm{t}, 2 \mathrm{~b}}\right)$. Furthermore we could specify that the old consumers are satiated at a low level of consumption. Such a model would imply that the middle-aged consumers would save primarily to bequeath wealth rather than to consume in their old age. This interpretation is reinforced by the empirical observation that the correlation between the consumption of the old and the stock market return is low.
} 


\section{$\left(c_{t, 1}, z_{t, 1} b e_{t, 1}\right)$ and the $\mathfrak{I}_{t+2}$-measurable $c_{t, 2}$.}

We consider two versions of the economy. In the borrowing-unconstrained version, the set of admissible consumption and investment policies is defined by the constraint (2.3) on the non-negativity of consumption and the budget constraints (2.4)-(2.5). These constraints, sometimes referred to as positive-net-worth constraints, rule out the possibility of personal bankruptcy even though the consumer may sell short the equity and the bond.

In the borrowing-constrained version of the economy, the set of admissible consumption and investment policies is defined by the condition that the equity and bond holdings must be non-negative, in addition to the constraints (2.3)-(2.5), which rule out negative consumption and personal bankruptcy.

The equilibrium of the particular borrowing-constrained economies that we calibrate has the property that the constraint on selling equity short is never binding. It is the constraint on selling the bond short that is binding in some, but not all the states, and captures the notion that borrowing is forbidden. Since our main results depend crucially on the assumption that borrowing is ruled out, this assumption merits careful examination.

The borrowing constraint may be challenged on the grounds that in reality consumers have the opportunity to purchase equities on margin and purchase index futures with small initial and maintenance margins. They may also borrow indirectly by purchasing the equity of highly levered firms and by purchasing index options. We investigate these possibilities in the context of the equilibrium of borrowing-constrained economies. In Section 5 we report that a very small margin suffices to deter a borrowing-unconstrained young consumer from purchasing equity on margin, index futures and highly levered forms of equity. Essentially, a young consumer is unwilling to sacrifice even a small amount of immediate consumption to put up as margin for the purchase of equity.

We conclude the description of the economy by specifying the joint stochastic process of the wage income and dividend. We assume that the wage income of the young is a constant ${ }_{w} 0$ and that the wage income of the old is equal to zero. Instead of specifying the joint process of the wage income of the middle-aged consumer and the dividend, $\left(w^{l} t, d_{t}\right)$, we choose to specify the joint process of the aggregate income and the wages of the middle-aged, $\left(y_{t}, w_{t}\right)$, where the aggregate income is defined as

$$
y_{t}=w^{0}+w_{t} l_{t} b+d_{t} \text {. }
$$

Our definition of aggregate income includes the (constant) coupon payment on government debt. 14 We

\footnotetext{
14 This definition appears to differ from the standard definition of the GDP which does not include the coupon payment on government debt. We justify our definition of the GDP as follows. In a more realistic model that takes into account the taxation
} 
model the joint process of the (de-trended) aggregate income and the wage income of the middle-aged as a time-stationary process. ${ }^{15}$ In the calibration, $y_{t}$ and ${ }_{w} l_{t}$ assume two values each. The four possible realizations of the pair $\left(y_{t}, w_{t} l\right)$ are represented by the state variable $s_{t}=j, j=1, \ldots, 4$. We model $s_{t}$ as a Markov process with a non-degenerate, unique, stationary probability distribution and denote by $\Pi$ the $4 \times 4$ transition probability matrix.

\section{EQUILIBRIUM}

We consider stationary rational expectations equilibria as in Lucas (1978). Equilibrium is defined as the set of consumption and investment policies of the consumers born in each period and the $\mathfrak{J}_{\mathrm{t}}$-measurable bond and stock prices $q^{b_{t}}$ and $q_{t} e_{t}$ in all periods such that: (a) each consumer's consumption and investment policy maximizes the consumer's expected utility from the set of admissible policies while taking the price processes as given; and (b) the bond and equity markets clear in all periods.

It is beyond the scope of this paper to characterize the full set of equilibria in the borrowingunconstrained economy. It turns out, however, that in the borrowing-unconstrained economy there exists a stationary equilibrium in which decisions made in period $\mathrm{t}$ and prices in period $\mathrm{t}$ are measurable with respect to the current state $s_{t}=j, j=1, \ldots, 4$, and the one-period lag of the investment decisions of the period-t middle aged, $z_{-1}^{e}$ and $z_{-1}^{b}$. Since in a stationary equilibrium the policy functions and prices are independent of calendar time, the notation is simplified by dropping the time subscript. Thus $z_{0}^{e}\left(j, z_{-1}^{e}, z_{-1}^{h}\right)$ and $z_{0}^{h}\left(j, z_{-1}^{e}, z_{-1}^{h}\right)$ are the equity and bond demand functions of the young; $z_{1}^{e}\left(j, z_{-1}^{e}, z_{-1}^{b}\right)$ and $z_{1}^{h}\left(j, z_{-1}^{e}, z_{-1}^{b}\right)$ are the equity and bond demand functions of the middle-aged; and $q^{e}\left(j, z_{-1}^{e}, z_{-1}^{h}\right)$, $q^{b}\left(j, z_{-1}^{c}, z_{-1}^{b}\right)$ are the price functions. A formal definition of this equilibrium is the following:

Definition: A stationary REE in the borrowing-unconstrained economy is a pair of sets $G_{z_{-1}^{e}}$ and $G_{z_{-1}^{b}}$ of possible values of stocks and bonds carried over by the middle-aged agents and a quadruple of demand functions

of wages and dividend by the government to service its debt. $w^{0}+w_{t}+d_{t}$ stands for the sum of the after-tax wages and dividend. The sum of the before-tax wages and dividend is obtained by adding $b$ to the after-tax wages and dividend, as in equation (2.9). In any case, the interest on government debt in the US is about $3 \%$ of the GDP and the calibration remains essentially unchanged whether the definition of the GDP includes the term $b$ or not.

$15 \mathrm{An}$ alternative plausible procedure is to model the joint process of the growth rate of the aggregate income and the ratio of the wage income of the middle-aged to aggregate income as a time-stationary process. See Mehra (1988). 


$$
\left.\begin{array}{l}
z_{0}^{e}\left(j, z_{-1}^{e}, z_{-1}^{h}\right) \\
z_{1}^{e}\left(j, z_{-1}^{e}, z_{-1}^{b}\right) \\
z_{0}^{b}\left(j, z_{-1}^{e}, z_{-1}^{b}\right) \\
z_{1}^{b}\left(j, z_{-1}^{e}, z_{-1}^{b}\right)
\end{array}\right\}:\{1,2,3,4\} \times G_{z_{-1}^{e}}, \times G_{z_{-1}^{h}} \rightarrow R
$$

together with a pair of price functions

$$
\left.\begin{array}{l}
q^{e}\left(j, z_{-1}^{e}, z_{-1}^{b}\right) \\
q^{h}\left(j, z_{-1}^{e}, z_{-1}^{h}\right)
\end{array}\right\}\left\{\{1,2,3,4\} \times G_{z_{-1}^{e}} \times G_{z_{-1}^{h}} \rightarrow R+\right.
$$

such that

and

$$
z_{0}^{e}\left(j, z_{-1}^{e}, z_{-1}^{b}\right) \in G_{z_{-1}^{e}},
$$

$$
z_{0}^{b}\left(j, z_{-1}^{e}, z_{-1}^{h}\right) \in G_{z_{-1}^{b}},
$$

jointly solve the following equations for each state $j$ :

(i) $u_{1}\left(w^{0}-q^{e}(j) z_{0}^{e}(j)-q^{h}(j) z_{0}^{b}(j)\right) \cdot q^{e}(j)$

$$
\begin{aligned}
=\beta \sum_{k=1}^{4} & u_{1}\left(\left[q^{e}\left(k, z_{0}^{e}(j), z_{0}^{b}(j)\right)+d_{k}\right] z_{0}^{e}(j)+\left[q^{b}\left(k, z_{0}^{e}(j), z_{0}^{h}(j)\right)+b\right] z_{o}^{b}(j)+w_{k}^{1}\right. \\
- & \left.q^{e}\left(k, z_{0}^{e}(j), z_{0}^{h}(j)\right) z_{1}^{e}\left(k, z_{0}^{e}(j), z_{0}^{b}(j)\right)-q^{h}\left(k, z_{0}^{e}(j), z_{0}^{h}(j)\right) z_{1}^{h}\left(k, z_{0}^{e}(j), z_{0}^{b}(j)\right)\right) \\
\cdot & {\left[q^{e}\left(k, z_{0}^{e}(j), z_{0}^{b}(j)\right)+d_{k}\right] \Pi_{j k} }
\end{aligned}
$$

(ii) $u_{1}\left(w^{0}-q^{e}(j) z_{0}^{e}(j)-q^{h}(j) z_{0}^{h}(j)\right) \cdot q^{h}(j)$

$$
\begin{aligned}
& =\beta \sum_{k=1}^{4} u_{1}\left(\left[q^{e}\left(k, z_{0}^{e}(j), z_{0}^{h}(j)\right)+d_{k}\right] z_{0}^{e}(j)+\left[q^{\prime \prime}\left(k, z_{0}^{e}(j), z_{0}^{b}(j)\right)+b\right] z_{o}^{\prime \prime}(j)+w_{k}^{1}\right. \\
& \left.-q^{e}\left(k, z_{0}^{e}(j), z_{0}^{h}(j)\right) z_{1}^{e}\left(k, z_{0}^{e}(j), z_{0}^{h}(j)\right)-q^{h}\left(k, z_{0}^{e}(j), z_{0}^{\prime \prime}(j)\right) z_{1}^{b}\left(k, z_{0}^{e}(j), z_{0}^{\prime \prime}(j)\right)\right) \\
& \cdot\left[q^{b}\left(k, z_{0}^{e}(j), z_{0}^{b}(j)\right)+b\right] \Pi_{j k}
\end{aligned}
$$

(iii) $u_{1}\left(\left[q^{e}(j)+d_{j}^{e}\right] z_{-1}^{e}+\left[q^{\prime \prime}(j)+b\right] z_{-1}^{\prime \prime}-q^{e}(j) z_{1}^{e}(j)-q^{b}(j) z_{1}^{b}(j)\right) q^{e}(j)$

$$
=\beta \sum_{k=1}^{4} u_{1}\left(\left[q^{e}\left(k, z_{0}^{e}(j), z_{0}^{b}(j)\right)+d_{k}\right] z_{1}^{e}(j)+\left[q^{h}\left(k, z_{0}^{e}(j), z_{0}^{b}(j)\right)+b\right] \cdot z_{1}^{b}(j)\right)
$$




$$
\cdot\left[q^{e}\left(k, z_{0}^{e}(j), z_{0}^{h}(j)\right)+d_{k}\right] \Pi_{j k}
$$

iv) $\quad u_{1}\left(\left[q^{e}(j)+d_{j}^{e}\right] z_{-1}^{e}+\left[q^{b}(j)+b\right] z_{-1}^{h}-q^{e}(j) z_{1}^{e}(j)-\mathrm{q}^{\mathrm{b}}(\mathrm{j}) \mathrm{z}_{1}^{\mathrm{b}}(\mathrm{j})\right) \mathrm{f}^{\mathrm{b}}(\mathrm{j})$

$$
\begin{aligned}
= & \beta \sum_{k=1}^{4} u_{1}\left(\left[q^{e}\left(k, z_{0}^{e}(j), z_{0}^{h}(j)\right)+d_{k}\right] z_{1}^{e}(j)+\left[q^{h}\left(k, z_{0}^{e}(j), z_{0}^{h}(j)\right)+b\right] \cdot z_{1}^{h}(j)\right) \\
& \cdot\left[q^{h}\left(k, z_{0}^{e}(j), z_{0}^{h}(j)\right)+b\right] \Pi_{j k}
\end{aligned}
$$

$$
z_{0}^{e}\left(j, z_{-1}^{e}, z_{-1}^{h}\right)+z_{1}^{e}\left(j, z_{-1}^{e}, z_{-1}^{b}\right)=1
$$

and

$$
z_{0}^{b}\left(j, z_{-1}^{c}, z_{-1}^{b}\right)+z_{1}^{b}\left(j, z_{-1}^{e}, z_{-1}^{b}\right)=1
$$

A stationary rational expectations equilibrium in the borrowing-unconstrained economy may be shown to exist. 16

In the borrowing-constrained economy we characterize the set of parameters for which the young find the borrowing constraint binding and choose not to short the equity (even though the restriction on short sales is not binding). This is the scenario which we aim to capture with the borrowing constraint. With these parameter values there exists a stationary equilibrium in which decisions made in period $t$ and prices in period $t$ are measurable with respect to the current state $s_{t}=j$, $\mathrm{j}=1, \ldots, 4$. Essentially, the consumer born in period $t-1$ enters period $t$ with zero holdings in the bond and equity; the state $s_{t-1}$ becomes irrelevant for decisions made in period $t$ and for prices in period $t$. A formal definition of the equilibrium in the borrowing-constrained economy is the following:

Definition: A stationary rational expectations equilibrium in the borrowing-constrained economy is a pair of price functions, $q^{e}(j)$ and $q^{h}(j)$, that satisfy:

$$
\mathrm{u}_{1}\left(\mathrm{w}^{1}(\mathrm{j})-\mathrm{q}^{\mathrm{c}}(\mathrm{j})-\mathrm{q}^{\mathrm{b}}(\mathrm{j})\right) \mathrm{q}^{\mathrm{b}}(\mathrm{j})=\beta \sum_{\mathrm{k}=1}^{4} \mathrm{u}_{1}\left(\left[\mathrm{q}^{\mathrm{c}}(\mathrm{k})+\mathrm{d}(\mathrm{k})\right]+\left[\mathrm{q}^{\mathrm{b}}(\mathrm{k})+\mathrm{b}\right]\right)\left(\mathrm{q}^{\mathrm{b}}(\mathrm{k})+\mathrm{b}\right) \Pi_{j \mathrm{k}}
$$

and

(ii) $\mathrm{u}_{1}\left(\mathrm{w}^{\mathrm{l}}(\mathrm{j})-\mathrm{q}^{\mathrm{e}}(\mathrm{j})-\mathrm{q}^{\mathrm{b}}(\mathrm{j})\right) \mathrm{q}^{\mathrm{c}}(\mathrm{j})=\beta \sum_{\mathrm{k}=1}^{4} \mathrm{u}_{1}\left(\mathrm{q}^{\mathrm{e}}(\mathrm{k})+\mathrm{d}(\mathrm{k})+\left[\mathrm{q}^{\mathrm{b}}(\mathrm{k})+\mathrm{b}\right]\right)\left[\mathrm{q}^{\mathrm{e}}(\mathrm{k})+\mathrm{d}(\mathrm{k})\right] \Pi_{\mathrm{jk}}$.

\footnotetext{
16 The outline of the proof is as follows. By the results in Balasko et al (1980, Section 4), our model is isomorphic to one in which agents live for two periods. In this latter context, Cass et. al. (1992), demonstrated existence of equilibrium for the case in which assets pay off in money. By Remark 2 of the same paper, this result can be extended to a model in which the asset payoffs are denominated in terms of the consumption good, provided the asset return matrix has full rank. This is the case in our model
} 
It is shown in Appendix A that a stationary rational expectations equilibrium in the borrowingconstrained economy exists. The numerical routine for calculating the equilibrium in both the borrowing-constrained and the unconstrained economies is outlined in Appendix B.

\section{CALIBRATION}

The preference parameters are the relative risk aversion (RRA) coefficient, $\alpha$, and the subjective discount factor, $\beta$. We present results for the plausible values $\alpha=2,4$ and 6 of the RRA coefficient. We set $\beta=.44$ for a period of length 20 years. This corresponds to an annual subjective discount factor of .96, which is standard in the macro-economic literature. ${ }^{17}$

The calibration of the joint Markov process on the wage income of the middle-aged consumers, $\mathrm{w}^{\mathrm{l}}$, and the aggregate income, $\mathrm{y}$, is simplified considerably by the observation that the equilibrium security prices in the borrowing-constrained economy are linear scale multiples of the wage and income variables. This follows from the homogeneity introduced by the constant-RRA preferences and is made precise in Lemma A.1 in Appendix A. A corresponding homogeneity result applies to the unconstrained economy.

This property of equilibrium security prices implies that the equilibrium joint probability distribution of the bond and equity returns is invariant to the level of the exogenous macro-economic variables for a fixed correlation structure. The distribution depends on (i) the average share of income going to labor, $E\left(\frac{w^{1}+w^{0}}{y}\right)$; (ii) the average share of income going to the labor of the young, $w^{0} / E[y]$; (iii) the average share of income going to interest on government debt, b/E[y]; (iv) the coefficient of variation of the 20-year wage income of the middle aged, $\sigma\left(\mathrm{w}^{1}\right) / \mathrm{E}\left(\mathrm{w}^{1}\right)$; (v) the coefficient of variation of the 20-year aggregate income, $\sigma(\mathrm{y}) / \mathrm{E}(\mathrm{y})$; and (vi) the 20-year autocorrelations and cross-correlation of the labor income of the middle-aged and the aggregate income, $\operatorname{corr}\left(\mathrm{y}_{\mathrm{t}}, \mathrm{y}_{\mathrm{t}-1}\right)$, corr $\left(w^{1} t, w^{1} t-1\right)$ and corr $\left(y_{t}, w^{1} t\right)$. Accordingly, we calibrate the model on ranges of the above moments (i)-(vi). There are enough degrees of freedom to permit the construction of a $4 \times 4$ transition matrix, $\Pi$, which exhibits a particular type of symmetry. 18

\footnotetext{
by construction.

17 We also calculated the equilibrium in economies with annual subjective discount factor equal to 1.04 . The results, not reported here, are insensitive to the value of the subjective discount factor.

${ }^{18}$ The joint process on income $(y)$ and wage of the middle-aged $\left(w^{l}\right)$ is modeled as a simple Markov chain with transition matrix
} 
The single most serious challenge to the calibration is the estimation of the above unconditional moments. Recall that the wage income of the middle-aged and the aggregate income are 20-year aggregates. Thus, even a century-long time series provides only five non-overlapping observations, resulting in large standard errors of the point estimates. Standard econometric methods designed to extract more information from the time series, such as the utilization of overlapping observations or the fitting of high-frequency, high-order, time-series models, only marginally increase the effective number of non-overlapping observations and leave the standard errors large. 19

We proceed with the estimation of the unconditional moments:

i. The average share of income going to labor, $E\left(\frac{w^{1}+w^{0}}{y}\right)$. In the U.S. economy this ratio is about .66 to .75 , depending on the historical period and the manner of adjusting capital income. The model considered in this paper, however, is implicitly concerned only with the fraction of the population which owns financial assets, at least at some stage of their life cycle. For the time period for which the equity premium puzzle was originally stated, about $25 \%$ of the population held financial assets (Mankiw and Zeldes (1991) and Blume and Zeldes (1993)); that fraction has risen to its current level of about $40 \%$. In our borrowing-constrained economy, the fraction of the population owning financial assets is .33 , midway between the aforementioned estimates. We acknowledge, however, that age is not the sole determinant of ownership of financial assets. In light of these comments we set the ratio $\mathrm{E}\left(\frac{\mathrm{w}^{1}+\mathrm{w}^{\prime \prime}}{\mathrm{y}}\right)$ in the range $(.60, .69)$.

ii. The average share of income going to the labor of the young, $w^{0} / E[y]$. This share is set in the range $(.16, .20)$, sufficiently small to guarantee that the young have the propensity to borrow and render the borrowing constraint binding in the borrowing-constrained economy.

iii. The average share of income going to interest on government debt, $\mathrm{b} / \mathrm{E}[\mathrm{y}]$. This was set at .03,

$\begin{gathered}\left(\mathrm{Y}_{1}, \mathrm{w}_{1}^{1}\right) \\ \left(\mathrm{Y}_{1}, \mathrm{w}_{2}^{1}\right) \\ \left(\mathrm{Y}_{2}, \mathrm{w}_{1}^{1}\right) \\ \left(\mathrm{Y}_{2}, \mathrm{w}_{2}^{1}\right)\end{gathered}\left[\begin{array}{cccc}\phi & \left(\mathrm{Y}_{1}, \mathrm{w}_{2}^{1}\right) & \left(\mathrm{Y}_{2}, \mathrm{w}_{1}^{1}\right) & \left(\mathrm{Y}_{2}, \mathrm{w}_{2}^{1}\right) \\ \pi+\Delta & \pi & \sigma & \mathrm{H} \\ \mathrm{H} & \phi-\Delta & \mathrm{H} & \sigma \\ \mathrm{H} & \sigma & \phi-\Delta & \pi+\Delta \\ & & \pi & \phi\end{array}\right]$.

Given the assumed symmetry of the transition matrix, there are only eight parameters to be determined: $\mathrm{Y}_{1}, \mathrm{Y}_{2}, \mathrm{~W}_{1}^{\mathrm{I}}$, $\mathrm{w}_{2}^{\prime}, \phi, \pi, \sigma, \Delta$ and $\mathrm{H}$. The parameters are chosen to satisfy the following eight conditions: (1) the six target moments, (i)-(vi) ; (2) the normalization $\mathrm{E}[\mathrm{y}]=1$; and (3) the conservation requirement that the row sums of the elements of the transition matrix are one.

19 We are indebted to Edward Prescott for numerous helpful discussions on calibration. 
consistent with the US historical experience.

iv. The coefficient of variation of the 20-year wage income of the middle aged, $\sigma\left(\mathrm{w}^{1}\right) / \mathrm{E}\left(\mathrm{w}^{1}\right)$. The comparative return distributions generated by the constrained and the unconstrained versions of the model depend crucially on this coefficient. Ideally we would like the calibration to reflect the fact that the young face large idiosyncratic uncertainty in their future labor income, generated by uncertainty in the choice of career and on their relative success in their chosen career. Nevertheless, consumer heterogeneity within a generation is disallowed in our formal model in order to isolate and explore the implications of heterogeneity across generations in a parsimonious way. Here, and in the estimation of the auto-correlations and cross-correlation in (vi), we shall merely invoke consumer heterogeneity as a justification for being liberal in estimating these moments.

We are unaware of any study which estimates the coefficient of variation of the 20-year (or, annual) wage income of the middle aged, $\sigma\left(\mathrm{w}^{\prime}\right) / \mathrm{E}\left(\mathrm{w}^{1}\right)$. Creedy (1985), in a study of select "white collar" professions in the U.K, estimated that the annual coefficient $\sigma(\mathrm{w}) / \mathrm{E}(\mathrm{w})$ is in the range 0.31-0.57 ; in a study of women, Cox (1984) estimated the coefficient to be about 0.25 . Gourinchas and Parker (1996) estimated the annual cross-sectional coefficient of variation to be about 0.5 . Taking the above estimates into account, we calibrate the coefficient of variation to be 0.25 .

v. The coefficient of variation of the 20-year aggregate income, $\sigma(\mathrm{y}) / \mathrm{E}(\mathrm{y})$. This coefficient captures the variation in detrended, 20-year, aggregate income. In the U.S. economy the log of the detrended ( Hodrick-Prescott filtered) quarterly aggregate income is highly autocorrelated and has standard deviation of about $1.8 \%$. This information provides little guidance in choosing the coefficient of variation of the 20-year aggregate income. We consider the values 0.20 and 0.25 .

vi. The 20-year auto-correlations and cross-correlation of the labor income of the middle-aged and the aggregate income, $\operatorname{corr}\left(\mathrm{y}_{\mathrm{t}}, \mathrm{w}_{\mathrm{t}}\right), \operatorname{corr}\left(\mathrm{y}_{\mathrm{t}}, \mathrm{y}_{\mathrm{t}-1}\right)$ and $\operatorname{corr}\left(\mathrm{w}_{1}^{1}, \mathrm{w}_{\mathrm{t}-1}^{1}\right)$. Lacking sufficient timeseries data to estimate the 20-year auto-correlations and cross-correlation, we present results for $\operatorname{corr}\left(\mathrm{y}_{\mathrm{t}}, \mathrm{y}_{\mathrm{t}-1}\right)=\operatorname{corr}\left(\mathrm{w}_{\mathrm{t}}^{1}, \mathrm{w}_{\mathrm{t}-1}^{1}\right)=0.1$ or $0.8 ;$ and $\operatorname{corr}\left(\mathrm{y}_{\mathrm{t}}, \mathrm{w}_{\mathrm{t}}\right)=0.1$ or 0.8 .

In Table 1 we report historical estimates of the mean and standard deviation of the annualized, 20-year holding-period-return on the CRSP value-weighted index of NYSE, AMEX and NASDAQ stocks; and on the Ibbotson US Government Treasury Long Term bond file. The mean (equity or bond) return is defined as $100 \times$ [ sample mean of the 20 -year holding period return $\}^{1 / 20}-1$ ]. The standard deviation of the (equity or bond) return is defined as $100 \times$ [ sample std \{(20-year holding period 
return $\left.)^{1 / 20}\right\}$ ]. We also report the mean equity premium, defined as the difference of the mean return on equity and the mean return on the bond; and the standard deviation of the premium, defined as $100 \mathrm{x}$ [ sample std $\left.\left.\left\{(20 \text {-year equity return })^{1 / 20} \text { - (20-year bond return }\right)^{1 / 20}\right\}\right]$. The relevant estimates for our purposes are on real returns and these cover the sample period 2/1947-12/1996, with 358 overlapping observations. We also report the estimates on nominal returns, as these cover the longer sample period 1/1926 - 12/1996, with 611 overlapping observations. We do not report standard errors, as these are large: on nominal returns we have only four and on real returns we have only two non-overlapping observations.

In Table 1 the (real) mean equity return is $5 \%-6 \%$ with a std of $3 \%-4 \%$; the mean bond return is about $1 \%$; and the mean equity premium is $5 \%-6 \%$. (We stress that what we refer to here as the std of equity return is the std of the annualized 20-year equity return, as defined above, and is very different than the std of the 1 -year equity return which is typically of the order of $16 \%$ annual). Since the "equity" in our model is the claim not just to corporate dividends but to all risky capital in the economy, the mean equity premium that we aim to match is about $3 \%$.

\section{RESULTS}

The properties of the stationary equilibria of the calibrated economies are reported in Tables 2-4. The annual subjective discount factor is set equal to .96 , the average share of income going to labor is setin the range $(.60, .69)$, the average share of income going to the labor of the young is set in the range ( $.16, .20)$ and the average share of income going to interest on government debt is set equal to .03 . In Table 2 we set $\operatorname{RRA}=6, \sigma(\mathrm{y}) / \mathrm{E}[\mathrm{y}]=0.20$ and $\sigma\left(\mathrm{w}^{1}\right) / \mathrm{E}\left[\mathrm{w}^{1}\right]=0.25$; in Table 3 we set RRA $=4, \sigma(\mathrm{y}) / \mathrm{E}[\mathrm{y}]=0.25$ and $\sigma\left(\mathrm{w}^{1}\right) / \mathrm{E}\left[\mathrm{w}^{1}\right]=0.25$; and in Table 4 we set RRA $=2, \sigma(\mathrm{y}) / \mathrm{E}[$ $\mathrm{y}]=0.25$ and $\sigma\left(\mathrm{w}^{1}\right) / \mathrm{E}\left[\mathrm{w}^{1}\right]=0.25$

In the tables the one-period (20-year) bond is referred to as the "bond". The bond is in zero net supply. In the borrowing-constrained case the bond price is defined as the private valuation of the bond by the middle-aged consumer. 20 In the unconstrained case the bond price is also defined as the private valuation of the bond by the middle-aged consumer. 21 The consol bond is referred to as the "consol".

\footnotetext{
20 Specifically, it is the shadow price of the bond determined by the marginal rate of substitution of the middle-aged consumer. It would be meaningless to report the private valuation of the bond by the young consumer because the young consumer would like to sell the bond short (borrow) but the borrowing constraint is binding.

21 Specifically, it is the shadow price of the bond determined by the marginal rate of substitution of the middle-aged consumer. The private valuation of the bond by the young consumer is also well defined. We have calculated both private valuations of the bond and they agree to the second decimal point. Essentially the two traded securities, the equity and the consol, come close to completing the market and the private valuation of the (one-period) bond by the young and the middle-aged practically coincide,
} 
The consol is in positive net supply.

The mean (equity, bond or consol) return is defined as $100 \times$ [ \{mean of the 20 -year holding period return $\}^{1 / 20}-1$ ]. The standard deviation of the (equity, bond or consol) return is defined as $100 \mathrm{x}$ [std $\left\{(20 \text {-year holding period return })^{1 / 20}\right\}$ ]. The mean premium of equity return over the bond return, "MEAN PRM/BOND", is defined as the difference of the mean return on equity and the mean return on the bond. The standard deviation of the premium of equity return over the bond return, "STD PRM/BOND", is defined as $100 \times$ [ sample std $\left\{(20 \text {-year equity return })^{1 / 20}\right.$ - (20-year bond return $\left.)^{1 / 20}\right\}$ ]. The mean premium of equity return over the consol return, "MEAN PRM/CONSOL", and the standard deviation of the premium of equity return over the consol return, "STD PRM/CONSOL", are defined in a similar manner.

The single most important observation across all the cases reported in Tables 2-4 is that the mean (20-year or consol) bond return roughly doubles when the borrowing constraint is relaxed. This observation is robust to the calibration of the correlation and auto-correlation of the labor income of the middle-aged and the aggregate income. Thus, the borrowing constraint goes a long way, albeit not all the way, towards alleviating the risk-free rate puzzle. This, of course, is the first part of the thesis of our paper: if the young are able to borrow, they do so and purchase equity; the borrowing activity of the young raises the bond return, thereby exacerbating the risk-free rate puzzle.

The second observation across all the borrowing-constrained cases reported in Tables 2-4 is that the minimum mean equity premium over the 20 -year bond is about half the target of $3 \%$. Further, the premium decreases when the borrowing constraint is relaxed. This is the second part of the thesis of our paper: if the young are able to borrow, the increase in the bond return induces the middle-aged to shift their portfolio holdings in favor of the bond; the increase in the demand for equity by the young and the decrease in the demand for equity by the middle-aged work in opposite directions; on balance, the effect is to increase both the equity and the bond return while simultaneously shrinking the equity premium. Whereas the mean equity premium decreases in all the cases when the borrowing constraint is relaxed, the amount by which the premium decreases is the largest in the top panels of Tables 2-4 in which the labor income of the middle-aged and the aggregate income are negatively correlated.

The third observation across all the cases reported in Tables $2-4$ is that the correlation of the labor income of the middle-aged and the equity premium over the 20 -year bond, $\operatorname{corr}\left(\mathrm{w}^{1}\right.$, PRM/BOND ), is much smaller in absolute value than the exogenously-imposed correlation of the labor income of the middle-aged and the dividend, $\operatorname{corr}\left(\mathrm{w}^{1}, \mathrm{~d}\right)$. Thus equity is attractive to the young because of the large 
mean equity premium and the low correlation of the premium with the wage income of the middle-aged, thereby corroborating another important ingredient of our story.

The fourth observation is that the borrowing constraint results in standard deviations of the annualized, 20-year equity and bond returns which are lower than in the unconstrained case and which are comparable to the target values in Table 1.

Since our main results depend critically on the assumption that borrowing is prohibited, this assumption merits careful examination. The restriction on borrowing against future labor income is realistic. However the restriction on borrowing to invest in equity may be challenged on the grounds that in reality consumers have the opportunity to purchase equity and stock index futures on margin and purchase a home with a $15 \%$ down-payment. We investigate these possibilities in the context of the equilibrium of the borrowing-constrained economies. We define $M$ to be the dollar amount that a consumer can borrow for one (20-year) period with one dollar down-payment and invest $\mathrm{M}+1$ dollars in equity on margin. That is, the margin requirement is $1 /(\mathrm{M}+1)$, which is approximately equal to $\mathrm{M}^{-1}$ for large $M$. We report the maximum value of $M$ that still deters young investors from purchasing equity on margin. Tables 2-4 display the value of $M$ in the equilibrium of all the borrowing-constrained economies. In all cases $\mathrm{M}$ exceeds the value of $55:$ a young consumer is unwilling to sacrifice even one dollar of immediate consumption to put up as margin for the purchase of equity worth $\$ 56$. This demonstrates that our results remain unchanged, if the borrowing constraint to purchase equity is replaced by even a small margin requirement of $2 \%$.

We also investigate the possibility that investors evade the margin requirement by purchasing the equity of a levered firm, where the "firm" is the claim to the dividend process. A simple variation of the above calculations shows that a margin requirement of $4 \%$ suffices to deter the borrowing-constrained young from purchasing the levered equity even if the debt-to-equity ratio is $1: 1$. We conclude that our results remain effectively unchanged even if we recognize the ability of firms to borrow.

Finally in Table 5 we present the consumption of the young, middle-aged and old and the conditional first moments of the returns at the four states of the borrowing-constrained economy. The economy is calibrated as in the first two columns of the top panel of Table 2 and corresponds to the case where $\mathrm{RRA}=6, \sigma(\mathrm{y}) / \mathrm{E}[\mathrm{y}]=0.20, \sigma\left(\mathrm{w}^{1}\right) / \mathrm{E}\left[\mathrm{w}^{1}\right]=0.25, \operatorname{corr}\left(\mathrm{y}_{\mathrm{t}}, \mathrm{y}_{\mathrm{t}-1}\right)=\operatorname{corr}\left(\mathrm{w}_{\mathrm{t}}^{1}, \mathrm{w}_{\mathrm{t}-1}^{1}\right)=$ 0.1 and $\operatorname{corr}\left(\mathrm{y}_{\mathrm{t},} \mathrm{w}_{\mathrm{t}}\right)=0.1$. As expected, the young simply consume their endowment, which in our model is constant across states. The consumption of the middle-aged is also fairly smooth. The consumption of the old is surprisingly variable; it is this variability that induces the middle-aged to invest 
partly in bonds, despite the high mean premium of equity over bonds. The conditional first moments of the returns are substantially different across the states.

\section{CONCLUDING REMARKS}

We have addressed ongoing questions on the historical mean and standard deviation of the returns on equities and bonds and on the equilibrium demand for these securities in the context of a stationary, overlapping-generations economy in which consumers are subject to a borrowing constraint. The particular combination of these elements captures the effect of the borrowing constraint on the investors' saving and dis-saving behavior over their life-cycle and provides answers to these questions.

The model is intentionally sparse in its assumptions in order to convey the basic message in the simplest possible way. It can be enriched in various ways that enhance its realism. For example, we may increase the number of generations from three to sixty, representing consumers of ages twenty to eighty in annual increments. In such a model we expect that the youngest consumers are borrowingconstrained for a number of years and invest neither in equity nor in bonds; thereafter they invest in a portfolio of equity and bonds, with the proportion of equity in their portfolio decreasing as they grow older and the attractiveness of equity diminishes.

We may increase the endowment of the young consumers to reflect inter-generational transfers; and we may make the endowment of the young random and different across consumers. These changes will have pricing implications to the extent that the young investors who are currently infra-marginal in the equity and bond markets become marginal. We may model the pension income and social security benefits of the old consumers. We may model the heterogeneity of consumers within a generation. We may model the GDP growth as a stationary process rather than modeling the (de-trended) GDP level as a stationary process. We may model distinct production sectors, endogenize production and endogenize the labor-leisure tradeoff. We may model the government sector in a more realistic way than we have done in the paper. We suspect that in all these cases the primary message of our paper will survive: the borrowing-constraint has the effect of lowering the interest rate and raising the equity premium. 


\section{References}

Abel, Andrew B. "Asset Prices under Habit Formation and Catching Up with the Joneses." A.E.R. Papers and Proc. 80 (May 1990): 38-42.

Aiyagari, S. Rao, and Gertler, Mark. "Asset Returns with Transactions Costs and Uninsured Individual Risk." J. Monetary Econ. 27 (June 1991): 311-31.

Auerbach, A. J. and Kotlikoff, L. J. Dynamic Fiscal Policy. Cambridge: Cambridge Univ. Press, 1987.

Alvarez, Fernando, and Jermann, Urban. "Asset Pricing when Risk Sharing is Limited by Default." Working paper. Chicago: Univ. Chicago, May 1997.

Balasko, Y.; Cass; David; and Shell, Karl. "Existence of Competitive Equilibrium in a General Equilibrium Overlapping-generations Model." J. Econ. Theory 23 (1980): 307-22.

Basak, Suleyman, and Cuoco, Domenico. "An Equilibrium Model with Restricted Stock Market Participation." The Review of Financial Studies, 11 (1998), 309-341.

Benartzi, Shlomo, and Thaler, Richard H. "Myopic Loss Aversion and the Equity Premium Puzzle." Quarterly J. Econ. 110 (1995): 73-92.

Bertaut, Carol C., and Haliassos, Michael. "Precautionary Portfolio Behavior from a Life-Cycle Perspective." J. of Econ. Dynamics and Control 21 (1997) ,1511-42.

Bewley, Truman F. "Thoughts on Tests of the Intertemporal Asset Pricing Model." Working paper. Evanston, Ill.: Northwestern Univ., 1982.

Blume, Marshall E., and Zeldes, Stephen P. "The Structure of Stock Ownership in the U.S." Working paper. Philadelphia: Univ. Pennsylvania, 1993.

Bodie, Zvi; Merton, Robert C.; and Samuelson, William F. "Labor Supply Flexibility and Portfolio Choice in a Life Cycle Model." J. Economic Dynamics and Control 16 (1992): 427-49.

Boldrin, Michele; Christiano, Lawrence J.; and Fisher, Jonas, D.M. "Asset Pricing Lessons for Modeling Business Cycles.” Unpublished paper. Evanston, IL: Northwestern Univ., 1996.

Brav, Alon, and Geczy, Christopher C. "An Empirical Resurrection of the Simple Consumption CAPM with Power Utility." Working paper. Chicago: Univ. of Chicago, 1995.

Campbell, John Y., and Cochrane, John H. "By Force of Habit: A Consumption-Based Explanation of Aggregate Stock Market Behavior.” NBER Working Paper No. 4995, 1995.

Cass, David; Green, Richard; and Spear, Stephen. "Stationary Equilibrium with Incomplete Markets and Overlapping Generations." International Economic Review, 33 (1992):495-512.

Cocco, Joao F.; Gomes, Francisco J.; and Maenhout, Pascal J. "Consumption and Portfolio Choice over 
the Life-Cycle." Working paper. Cambridge, Mass.: Harvard Univ., 1997.

Cochrane, John H., and Hansen, Lars Peter. "Asset Pricing Explorations for Macroeconomics." In NBER, Macroeconomics Annual, edited by Olivier J. Blanchard and Stanley Fischer, Cambridge, Mass.: M.I.T. Press, 1992.

Constantinides, George M. "Habit Formation: A Resolution of the Equity Premium Puzzle." J.P.E. 98 (June 1990): 519-43.

Constantinides, George M., and Duffie, Darrell. “Asset Pricing with Heterogeneous Consumers." J.P.E. 104 (1996): 219-240.

Cox, D. "Inequality in the Lifetime Earnings of Women." Review of Econ. and Statistics 64 (1984): 501-4.

Creedy, J. "Dynamics of Income Distribution." Oxford: Basil Blackwell, 1985.

Daniel, Kent, and Marshall, David. "The Equity Premium Puzzle and the Risk-Free Rate Puzzle at Long Horizons." Macroeconomic Dynamics, forthcoming, 1997.

Danthine, Jean-Pierre; Donaldson, John B.; and Mehra, Rajnish. "The Equity Premium and the Allocation of Income Risk." J. Econ. Dynamics and Control 16 (July-October 1992): 509-32.

Detemple, Jerome B., and Serrat, Angel. "Dynamic Equilibrium with Liquidity Constraints." Mimeo. Chicago: Univ. Chicago, 1996.

Donaldson, John B. and Mehra, Rajnish. "Comparative Dynamics of an Equilibrium Intertemporal Asset Pricing Model" Review of Economic Studies 51 (1984) : 491-508.

Epstein, Larry G., and Zin, Stanley E. "Substitution, Risk Aversion, and the Temporal Behavior of Consumption and Asset Returns: An Empirical Analysis." J.P.E. 99 (April 1991): 263-86.

Ferson, Wayne E., and Constantinides, George M. "Habit Persistence and Durability in Aggregate Consumption." J. Financial Econ. 29 (1991) 199-240.

Gakidis, Haralabos E. "Stocks for the Old? Earnings Uncertainty and Life-Cycle Portfolio Choice." Working paper. Cambridge, Mass.: M.I.T., 1997.

Gourinchas, Pierre-Olivier, and Parker, Jonathan A. "Consumption over the Lifecycle." Working paper. Cambridge, Mass.: Dept. Econ., M.I.T, 1996.

Haliassos, Michael, and Bertaut, Carol C. "Why Do So Few Hold Stocks?" The Economic J. 105 (1995): 1110-29.

Haliassos, Michael, and Hassapis, Christis. "Non-Expected Utility, Saving and Portfolios." Working paper. Cyprus: Univ. Cyprus, 1997.

Hansen, Lars Peter, and Jagannathan, Ravi. "Implications of Security Market Data for Models of 
Dynamic Economies." J.P.E. 99 (April 1991): 225-62.

Hansen, Lars Peter, and Singleton, Kenneth J. "Generalized Instrumental Variables Estimation of Nonlinear Rational Expectations Models.” Econometrica 50 (1982): 1269-88.

He, Hua, and Modest, David M. "Market Frictions and Consumption-Based Asset Pricing." J.P.E. 103 (February 1995): 94-117.

Heaton, John, and Lucas, Deborah J. "Evaluating the Effects of Incomplete Markets on Risk Sharing and Asset Pricing." J.P.E 104 (June 1996): 443-87.

, and Lucas, Deborah J. "Market Frictions, Savings Behavior and Portfolio Choice." Journal of Macroeconomic Dynamics, forthcoming, 1997a.

, and Lucas, Deborah J. "Portfolio Choice and Asset Prices: The Importance of Entrepreneurial Risk.” Working paper. Evanston, IL: Northwestern Univ., 1997b.

Jagannathan, Ravi, and Kocherlakota, Narayana R. "Why Should Older People Invest Less in Stocks Than Younger People?" Federal Bank of Minneapolis Quarterly Review 20 (1996): 11-23.

Kocherlakota, Narayana R. "The Equity Premium: It's Still a Puzzle.” J. Econ. Literature, 34 (March 1996): $42-71$.

Lucas, Deborah J. "Asset Pricing with Undiversifiable Risk and Short Sales Constraints: Deepening the Equity Premium Puzzle.” J. of Monetary Econ. 34 (1994): 325-41.

Lucas, Robert E., Jr. "Asset Prices in an Exchange Economy." Econometrica 46 (November 1978): $1429-45$.

Luttmer, Erzo G. J. "Asset Pricing in Economies with Frictions." Econometrica 64 (1996): 1439-67.

Mankiw, N. Gregory, "The Equity Premium and the Concentration of Aggregate Shocks." J. Financial Econ. 17 (September 1986): 211-19.

Mankiw, N. Gregory, and Zeldes, Stephen P. "The Consumption of Stockholders and Nonstockholders." J. Financial Econ. 29 (March 1991): 97-112.

Mehra, Rajnish, "On the Existence and Representation of Equilibrium in an Economy with Growth and Nonstationary Consumption," International Economic Review, 29 (February 1988): 131-135.

Mehra, Rajnish, and Prescott, Edward C. "The Equity Premium: A Puzzle." J. Monetary Econ. 15 (March 1985): 145-61.

Mehra, Rajnish, and Prescott, Edward C. "The Equity Premium: A Solution ?." J. Monetary Econ. 22 (July 1988): 133-36.

Prescott, Edward C., and Mehra, Rajnish "Recursive Competitive Equilibrium : The Case of 
Homogeneous Households" Econometrica 48 (1980): 1365-79.

Rietz, Thomas A. "The Equity Risk Premium: A Solution." J. Monetary Econ. 22 (1988): 117-31.

Rios-Rull, Jose-Victor, "On the Quantitative Importance of Market Completeness." J. Monetary Econ. 34 (1994): 463-96.

Storesletten, Kjetil; Telmer, Chris; and Yaron, Amir. "Persistent Idiosyncratic Shocks and Incomplete Markets." Working paper. Pittsburgh: Carnegie Mellon Univ., 1997.

Telmer, Chris I. “Asset-Pricing Puzzles and Incomplete Markets.” J. Finance 49 (1993): 1803-32.

Viceira, Luis M. "Optimal Portfolio Choice with Finite Retirement Horizons and Nontradeable Labor Income." Working paper. Cambridge, Mass.: Harvard Univ., 1997.

Weil, Philippe. "The Equity Premium Puzzle and the Risk-Free Rate Puzzle." J. Monetary Econ. 24 (November 1989): 401-21. 
TABLE 1

Real Returns 2/1947 - 12/1996

\author{
EQUITY BOND PREMIUM
}

$\begin{array}{cccc}\text { MEAN } & 5.5 \% & 0.12 \% & 5.38 \% \\ \text { STD } & 3.26 \% & 2.14 \% & 3.33 \%\end{array}$

\title{
Nominal Returns $1 / 1926$ - 12/1996
}

EQUITY BOND PREMIUM

$\begin{array}{lccc}\text { MEAN } & 11 \% & 4.02 \% & 6.98 \% \\ \text { STD } & 3.18 \% & 2.68 \% & 4.19 \%\end{array}$

We report empirical estimates of the mean and standard deviation of the annualized, 20-year holding-period-return on the CRSP value-weighted index of NYSE, AMEX and NASDAQ stocks; and on the Ibbotson US Government Treasury Long Term bond file. The mean return (on equity or the bond) is defined as $100 \times$ [ $\{\text { sample mean of the } 20 \text {-year holding period return }\}^{1 / 20}-1$ ]. The standard deviation of the (equity or bond) return is defined as $100 \mathrm{x}$ [ sample std $\left.\left\{(20 \text {-year holding period return })^{1 / 20}\right\}\right]$. The mean premium is defined as the difference of the mean return on equity and the mean return on the bond. The standard deviation of the premium is defined as $100 \times$ [ sample std $\left\{(20 \text {-year equity return })^{1 / 20}-(20 \text {-year bond return })^{1 / 20}\right\}$ ]. Estimates on real returns cover the sample period 2/1947 - 12/1996, with 358 overlapping observations. Estimates on nominal returns cover the sample period 1/1926-12/1996, with 611 overlapping observations. 
TABLE $2^{\mathrm{a}}$

\begin{tabular}{|c|c|c|c|c|}
\hline & \multicolumn{4}{|c|}{ CORRELATION $\left(\mathrm{y}, \mathrm{w}^{1}\right)=0.1$} \\
\hline & \multicolumn{2}{|c|}{$\begin{array}{l}\text { LOW SERIAL AUTOCORR. } \\
\text { OF y AND OF } w^{1}(0.1)\end{array}$} & \multicolumn{2}{|c|}{$\begin{array}{l}\text { HIGH SERIAL AUTOCORR. } \\
\text { OF y AND OF } w^{1}(0.8)\end{array}$} \\
\hline & $\begin{array}{l}\text { BORROWING } \\
\text { CONSTRAINED }\end{array}$ & $\begin{array}{c}\text { BORROWING } \\
\text { UNCONSTRAINED }\end{array}$ & $\begin{array}{l}\text { BORROWING } \\
\text { CONSTRAINED }\end{array}$ & $\begin{array}{c}\text { BORROWING } \\
\text { UNCONSTRAINED }\end{array}$ \\
\hline MEAN EQUITY RET. & 8.9 & 11.2 & 9.0 & 11.1 \\
\hline STD OF EQUITY RET. & 5.6 & 10.3 & 5.7 & 9.9 \\
\hline MEAN BOND RET. & 5.3 & 9.7 & 5.4 & 9.8 \\
\hline STD OF BOND RET. & 3.6 & 6.8 & 3.6 & 6.6 \\
\hline MEAN PRM/BOND & 3.7 & 1.5 & 3.6 & 1.6 \\
\hline STD PRM/BOND & 4.5 & 7.7 & 4.6 & 7.4 \\
\hline MEAN CONSOL RET. & 3.9 & 10.6 & 4.3 & 10.7 \\
\hline STD OF CONSOL RET & 4.4 & 6.9 & 4.4 & 6.7 \\
\hline MEAN PRM/CONSOL & 5.0 & 0.6 & 4.7 & 0.4 \\
\hline STD PRM/CONSOL & 6.4 & 6.7 & 6.6 & 6.3 \\
\hline MARGIN $^{-1}, \mathrm{M}$ & 178 & N.A. & 170 & N.A. \\
\hline $\operatorname{CORR}\left(w^{1}, d\right)$ & -0.43 & -0.43 & -0.38 & -0.38 \\
\hline $\begin{array}{l}\text { CORR( } w^{\prime} \\
\text { PRM/BOND) }\end{array}$ & -0.05 & 0.00 & -0.06 & 0.00 \\
\hline
\end{tabular}

\begin{tabular}{|c|c|c|c|c|}
\hline & \multicolumn{4}{|c|}{ CORRELATION $\left(\mathrm{y}, \mathrm{w}^{1}\right)=0.8$} \\
\hline & \multicolumn{2}{|c|}{$\begin{array}{c}\text { LOW SERIAL AUTOCORR. } \\
\text { OF y AND OF } w^{\prime}(0.1)\end{array}$} & \multicolumn{2}{|c|}{$\begin{array}{l}\text { HIGH SERIAL AUTOCORR. } \\
\text { OF y AND OF w }{ }^{1}(0.8)\end{array}$} \\
\hline & $\begin{array}{l}\text { BORROWING } \\
\text { CONSTRAINED }\end{array}$ & $\begin{array}{c}\text { BORROWING } \\
\text { UNCONSTRAINED }\end{array}$ & $\begin{array}{l}\text { BORROWING } \\
\text { CONSTRAINED }\end{array}$ & $\begin{array}{c}\text { BORROWING } \\
\text { UNCONSTRAINED }\end{array}$ \\
\hline MEAN EQUITY RET. & 8.3 & 13.7 & 8.1 & 14.5 \\
\hline STD OF EQUITY RET. & 4.6 & 7.5 & 3.4 & 4.5 \\
\hline MEAN BOND RET. & 6.1 & 12.1 & 6.3 & 13.0 \\
\hline STD OF BOND RET. & 3.8 & 6.4 & 3.2 & 4.2 \\
\hline MEAN PRM/BOND & 2.2 & 1.6 & 1.8 & 1.5 \\
\hline STD PRM/BOND & 2.7 & 3.3 & 2.0 & 2.0 \\
\hline MEAN CONSOL RET. & 6.8 & 12.8 & 7.1 & 13.3 \\
\hline STD OF CONSOL RET & 4.1 & 6.7 & 3.2 & 4.3 \\
\hline MEAN PRM/CONSOL & 1.5 & 0.9 & 1.0 & 1.2 \\
\hline STD PRM/CONSOL & 3.0 & 2.6 & 1.5 & 1.6 \\
\hline MARGIN $^{-1}, \mathrm{M}$ & 164 & N.A. & 156 & N.A. \\
\hline $\operatorname{CORR}\left(w^{\prime}, d\right)$ & .55 & 0.55 & 0.91 & 0.91 \\
\hline $\begin{array}{l}\text { CORR }\left(w^{1}\right. \\
\text { PRM/BOND) }\end{array}$ & -0.02 & -0.04 & 0.22 & 0.13 \\
\hline
\end{tabular}

a We set $R R A=6, \sigma(y) / E[y]=0.20$ and $\sigma\left(w^{1}\right) / E\left[w^{1}\right]=0.25$. The variables are defined in the main text of the paper. The consol bond is in positive net supply and the one-period (20-year) bond is in zero net supply. 
TABLE $3^{\text {a }}$

\begin{tabular}{|c|c|c|c|c|}
\hline & \multicolumn{4}{|c|}{ CORRELATION $\left(y, w^{1}\right)=0.1$} \\
\hline & \multicolumn{2}{|c|}{$\begin{array}{l}\text { LOW SERIAL AUTOCORR. } \\
\text { OF y AND OF } w^{\prime}(0.1)\end{array}$} & \multicolumn{2}{|c|}{$\begin{array}{l}\text { HIGH SERIAL AUTOCORR. } \\
\text { OF y AND OF } w^{1}(0.8)\end{array}$} \\
\hline & $\begin{array}{l}\text { BORROWING } \\
\text { CONSTRAINED }\end{array}$ & $\begin{array}{c}\text { BORROWING } \\
\text { UNCONSTRAINED }\end{array}$ & $\begin{array}{l}\text { BORROWING } \\
\text { CONSTRAINED }\end{array}$ & $\begin{array}{l}\text { BORROWING } \\
\text { UNCONSTRAINED }\end{array}$ \\
\hline MEAN EQUITY RET. & 9.7 & 13.2 & 9.6 & 13.4 \\
\hline STD OF EQUITY RET. & 4.7 & 7.4 & 4.6 & 7.1 \\
\hline MEAN BOND RET. & 6.8 & 10.9 & 6.8 & 11.1 \\
\hline STD OF BOND RET. & 3.6 & 5.4 & 3.5 & 5.0 \\
\hline MEAN PRM/BOND & 3.0 & 2.3 & 2.9 & 2.3 \\
\hline STD PRM/BOND & 3.3 & 5.2 & 3.0 & 5.2 \\
\hline MEAN CONSOL RET. & 6.0 & 11.4 & 6.1 & 11.5 \\
\hline STD OF CONSOL RET & 4.1 & 5.6 & 4.0 & 5.2 \\
\hline MEAN PRM/CONSOL & 3.7 & 1.8 & 3.5 & 1.9 \\
\hline STD PRM/CONSOL & 4.4 & 4.6 & 4.5 & 4.6 \\
\hline MARGIN $^{-1}, \mathrm{M}$ & 140 & NA & 142 & NA \\
\hline $\operatorname{CORR}\left(w^{\prime}, d\right)$ & -0.30 & -0.30 & -0.24 & -0.24 \\
\hline $\begin{array}{l}\text { CORR( } w^{\prime} \\
\text { PRM/BOND) }\end{array}$ & -0.04 & 0.00 & -0.04 & .01 \\
\hline
\end{tabular}

\begin{tabular}{|c|c|c|c|c|}
\hline & \multicolumn{4}{|c|}{ CORRELATION $\left(\mathrm{y}, \mathrm{w}^{\prime}\right)=0.8$} \\
\hline & \multicolumn{2}{|c|}{$\begin{array}{l}\text { LOW SERIAL AUTOCORR. } \\
\text { OF y AND OF } w^{1}(0.1)\end{array}$} & \multicolumn{2}{|c|}{$\begin{array}{l}\text { HIGH SERIAL AUTOCORR. } \\
\text { OF y AND OF } w^{\prime}(0.8)\end{array}$} \\
\hline & $\begin{array}{l}\text { BORROWING } \\
\text { CONSTRAINED }\end{array}$ & $\begin{array}{c}\text { BORROWING } \\
\text { UNCONSTRAINED }\end{array}$ & $\begin{array}{l}\text { BORROWING } \\
\text { CONSTRAINED }\end{array}$ & $\begin{array}{c}\text { BORROWING } \\
\text { UNCONSTRAINED }\end{array}$ \\
\hline MEAN EQUITY RET. & 9.2 & 13.9 & 9.1 & 14.4 \\
\hline STD OF EQUITY RET. & 4.2 & 6.3 & 3.0 & 4.0 \\
\hline MEAN BOND RET. & 6.9 & 12.1 & 7.1 & 12.6 \\
\hline STD OF BOND RET. & 3.4 & 5.3 & 2.5 & 3.4 \\
\hline MEAN PRM/BOND & 2.3 & 1.9 & 2.0 & 1.7 \\
\hline STD PRM/BOND & 2.6 & 3.2 & 2.3 & 2.4 \\
\hline MEAN CONSOL RET. & 7.5 & 12.5 & 7.6 & 12.9 \\
\hline STD OF CONSOL RET & 3.6 & 5.5 & 2.5 & 3.5 \\
\hline MEAN PRM/CONSOL & 1.7 & 1.4 & 1.5 & 1.5 \\
\hline STD PRM/CONSOL & 2.5 & 2.7 & 1.8 & 2.1 \\
\hline $\mathrm{MARGIN}^{-1}, \mathrm{M}$ & 162 & NA & 151 & NA \\
\hline $\operatorname{CORR}\left(w^{\prime}, d\right)$ & 0.69 & 0.69 & 0.95 & 0.95 \\
\hline $\begin{array}{l}\text { CORR( } w^{\prime} \\
\text { PRM/BOND) }\end{array}$ & -0.02 & -0.03 & 0.20 & 0.13 \\
\hline
\end{tabular}

a We set $\operatorname{RRA}=4, \sigma(\mathrm{y}) / \mathrm{E}[\mathrm{y}]=0.25$ and $\sigma\left(\mathrm{w}^{1}\right) / \mathrm{E}\left[\mathrm{w}^{1}\right]=0.25$. The variables are defined in the main text of the paper. The consol bond is in positive net supply and the one-period (20-year) bond is in zero net supply. 
TABLE $4^{\mathrm{a}}$

CORRELATION $\left(\mathrm{y}, \mathrm{w}^{\mathrm{l}}\right)=0.1$

\begin{tabular}{|c|c|c|c|c|}
\hline & \multicolumn{4}{|c|}{ CORRELATION $\left(\mathrm{y}, \mathrm{w}^{\mathrm{l}}\right)=0.1$} \\
\hline & \multicolumn{2}{|c|}{$\begin{array}{l}\text { LOW SERIAL AUTOCORR. } \\
\text { OF y AND OF } w^{\prime}(0.1)\end{array}$} & \multicolumn{2}{|c|}{$\begin{array}{l}\text { HIGH SERIAL AUTOCORR. } \\
\text { OF y AND OF w } w^{1}(0.8)\end{array}$} \\
\hline & $\begin{array}{l}\text { BORROWING } \\
\text { CONSTRAINED }\end{array}$ & $\begin{array}{c}\text { BORROWING } \\
\text { UNCONSTRAINED }\end{array}$ & $\begin{array}{l}\text { BORROWING } \\
\text { CONSTRAINED }\end{array}$ & $\begin{array}{c}\text { BORROWING } \\
\text { UNCONSTRAINED }\end{array}$ \\
\hline MEAN EQUITY RET. & 8.7 & 9.2 & 8.6 & 9.3 \\
\hline STD OF EQUITY RET. & 3.9 & 5.0 & 3.9 & 4.8 \\
\hline MEAN BOND RET. & 6.8 & 8.6 & 6.8 & 8.6 \\
\hline STD OF BOND RET. & 2.6 & 2.4 & 2.5 & 2.2 \\
\hline MEAN PRM/BOND & 1.9 & 0.6 & 1.8 & 0.6 \\
\hline STD PRM/BOND & 3.2 & 4.4 & 3.2 & 4.3 \\
\hline MEAN CONSOL RET. & 6.4 & 8.8 & 6.4 & 8.8 \\
\hline STD OF CONSOL RET & 2.9 & 2.5 & 2.9 & 2.3 \\
\hline MEAN PRM/CONSOL & 2.3 & 0.4 & 2.2 & 0.5 \\
\hline STD PRM/CONSOL & 4.0 & 0.4 & 3.9 & 0.4 \\
\hline $\mathrm{MARGIN}^{-1}, \mathrm{M}$ & 55 & NA & 55 & NA \\
\hline $\operatorname{CORR}\left(w^{\prime}, d\right)$ & -0.30 & -0.30 & -0.24 & -0.24 \\
\hline $\begin{array}{l}\operatorname{CORR}\left(w^{1}\right. \\
\text { PRM/BOND) }\end{array}$ & -0.03 & 0.00 & -0.03 & 0.00 \\
\hline
\end{tabular}

CORRELATION $\left(y, w^{\prime}\right)=0.8$

\begin{tabular}{|c|c|c|c|c|}
\hline & \multicolumn{4}{|c|}{ 年, } \\
\hline & \multicolumn{2}{|c|}{$\begin{array}{c}\text { LOW SERIAL AUTOCORR. } \\
\text { OF y AND OF } w^{\prime}(0.1)\end{array}$} & \multicolumn{2}{|c|}{$\begin{array}{l}\text { HIGH SERIAL AUTOCORR. } \\
\text { OF y AND OF } w^{\prime}(0.8)\end{array}$} \\
\hline & $\begin{array}{l}\text { BORROWING } \\
\text { CONSTRAINED }\end{array}$ & $\begin{array}{c}\text { BORROWING } \\
\text { UNCONSTRAINED }\end{array}$ & $\begin{array}{l}\text { BORROWING } \\
\text { CONSTRAINED }\end{array}$ & $\begin{array}{c}\text { BORROWING } \\
\text { UNCONSTRAINED }\end{array}$ \\
\hline MEAN EQUITY RET. & 8.4 & 9.7 & 8.4 & 9.8 \\
\hline STD OF EQUITY RET. & 3.2 & 3.7 & 2.4 & 2.6 \\
\hline MEAN BOND RET. & 7.2 & 8.9 & 7.4 & 9.1 \\
\hline STD OF BOND RET. & 2.3 & 2.5 & 1.4 & 1.5 \\
\hline MEAN PRM/BOND & 1.2 & 0.8 & 1.0 & 0.8 \\
\hline STD PRM/BOND & 2.4 & 2.7 & 2.1 & 2.1 \\
\hline MEAN CONSOL RET. & 7.4 & 9.1 & 7.5 & 9.2 \\
\hline STD OF CONSOL RET & 2.5 & 2.6 & 1.4 & 1.5 \\
\hline MEAN PRM/CONSOL & 1.0 & 0.6 & 0.8 & 0.6 \\
\hline STD PRM/CONSOL & 2.2 & 2.3 & 1.8 & 1.9 \\
\hline MARGIN $^{-1}, \mathrm{M}$ & 65 & NA & 56 & $\mathrm{NA}$ \\
\hline $\operatorname{CORR}\left(w^{1}, d\right)$ & 0.69 & 0.69 & 0.95 & 0.95 \\
\hline $\begin{array}{l}\text { CORR( } w^{\prime} \\
\text { PRM/BOND) }\end{array}$ & -0.01 & -0.00 & 0.06 & 0.04 \\
\hline
\end{tabular}

a We set RRA $=2, \sigma(y) / E[y]=0.25$ and $\sigma\left(w^{1}\right) / E\left[w^{1}\right]=0.25$. The variables are defined in the main text of the paper. The consol bond is in positive net supply and the one-period (20-year) bond is in zero net supply. 
TABLE $5^{\mathbf{a}}$

\begin{tabular}{|l|c|c|c|c|c|}
\cline { 2 - 6 } \multicolumn{1}{c|}{} & STATE 1 & STATE 2 & STATE 3 & STATE 4 & UNCONDITIONAL \\
\hline PROBABILITY & .273 & .227 & .225 & .225 & NA \\
\hline $\begin{array}{l}\text { CONSUMPTION OF THE } \\
\text { YOUNG }\end{array}$ & 19,000 & 19,000 & 19,000 & 19,000 & NA \\
\hline $\begin{array}{l}\text { CONSUMPTION OF THE } \\
\text { MIDDLE-AGED }\end{array}$ & 36,967 & 33,003 & 27,335 & 28,539 & NA \\
\hline $\begin{array}{l}\text { CONSUMPTION OF THE } \\
\text { OLD }\end{array}$ & 62,232 & 26,594 & 71,864 & 31,058 & NA \\
\hline MEAN EQUITY RETURN & 4.8 & 5.7 & 13.9 & 11.7 & 8.9 \\
\hline MEAN BOND RETURN & 2.5 & 0.8 & 7.7 & 9.6 & 5.3 \\
\hline MEAN PRM/BOND & 2.3 & 4.9 & 6.2 & 2.1 & 3.7 \\
\hline MEAN CONSOL RETURN & 2.3 & -1.5 & 4.8 & 9.2 & 3.9 \\
\hline MEAN PRM/CONSOL & 2.5 & 7.2 & 9.1 & 2.5 & 5.0 \\
\hline MARGIN ${ }^{-1}, M$ & 1212 & 386 & 178 & 373 & 178 \\
\hline
\end{tabular}

a $W e$ set $R R A=6, \sigma(y) / E[y]=0.20, \sigma\left(w^{1}\right) / E\left[w^{l}\right]=0.25, \operatorname{corr}\left(y_{t}, y_{t-1}\right)=\operatorname{corr}\left(w_{t}^{1}, w_{t-1}^{1}\right)=0.1$ and $\operatorname{corr}\left(y_{1}, w_{t}\right)=0.1$. The variables are defined in the main text of the paper. The consol bond is in positive net supply and the one-period (20-year) bond is in zero net supply. 


\section{APPENDIX A: Existence of Equilibrium in the Borrowing-Constrained EconomyA1}

Lemma A.1: Let the period utility function $u(c)$ be of the form $u(c)=c^{\gamma} / \gamma$. If $\left\{\left(q_{j}^{e}, q_{j}^{b}\right): j=1,2,3,4\right\}$ constitutes an equilibrium for the economy defined by $\left\{\left(y_{j}, w_{j}, w_{0}, B\right): j=1,2,3,4\right\}$, then for any $\lambda>0$, $\left\{\left(\lambda q_{j}^{\prime \prime}, q_{j}^{\prime \prime}\right): j=1,2,3,4\right\}$ is an equilibrium for the economy defined by $\left\{\left(\lambda y_{j}, \lambda w_{i}^{i}, \lambda w_{0}, \lambda B\right): j=1,2,3,4\right\}$.

Proof: Under the specified utility function, $\left\{\left(q_{j}^{e}, q_{j}^{h}\right): j=1,2,3,4\right\}$ must satisfy, for $j=1,2,3,4$,

$$
\begin{aligned}
& \frac{q_{j}^{e}}{\left(w_{j}^{1}-q_{j}^{e}-q_{j}^{b} B\right)^{1-\gamma}}=\beta \sum_{k=1}^{4} \frac{\left(q_{k}^{e}+d_{k}^{e}\right) \Pi_{j k}}{\left(\left[q_{k}^{e}+d_{k}^{e}\right]+\left[q_{k}^{h}+1\right] B\right)^{1-\gamma}}, \text { and } \\
& \frac{q_{j}^{b}}{\left(w_{j}^{1}-q_{j}^{e}-q_{j}^{l} B\right)^{1-\gamma}}=\beta \sum_{k=1}^{4} \frac{\left(q_{k}^{b}+1\right) \Pi_{j k}}{\left(\left[q_{k}^{e}+d_{k}^{e}\right]+\left[q_{k}^{h}+1\right] B\right)^{1-\gamma}}
\end{aligned}
$$

Now consider the economy defined by $\left\{\left(\theta y_{j}, \theta w_{j}, \theta w, \theta B\right): j=1,2,3,4\right\}$. It follows from equations (i) that:

$$
\frac{\lambda q_{j}^{e}}{\left(\lambda w_{j}^{1}-\lambda q_{j}^{e}-q_{j}^{b} \lambda B\right)^{1-\gamma}}=\beta \sum_{k=1}^{4} \frac{\left(\lambda q_{k}^{e}+\lambda d_{k}^{e}\right) \Pi_{j k}}{\left(\left[\lambda q_{k}^{e}+\lambda d_{k}^{e}\right]+\left[q_{k}^{b}+1\right] \gamma B\right)^{1-\gamma}}
$$

It similarly follows from equation (ii) that

$$
\frac{q_{j}^{h}}{\left(\lambda w_{j}^{1}-\lambda q_{j}^{e}-q_{j}^{b} \lambda B\right)^{1-\gamma}}=\beta \sum_{k=1}^{4} \frac{\left(q_{k}^{b}+1\right) \Pi_{j k}}{\left(\left[\lambda q_{k}^{e}+\lambda d_{k}^{e}\right]+\left[q_{k}^{b}+1\right] \gamma B\right)^{1-\gamma}}
$$

with equations (i) ${ }^{\prime}$ and (ii)' holding for all states $j=1,2,3,4$. Since

$$
\lambda d_{j}^{e}=\lambda y_{j}-\lambda w_{j}^{1}-\lambda w_{0}-\lambda B
$$

equations (i)' and (ii)' confirm that $\left\{\left(\lambda q_{j}^{e}, q_{j}^{b}\right): j=1,2,3,4\right\}$ constitutes an equilibrium for the economy characterized by $\left\{\left(\lambda y_{j}, \lambda w_{j}^{i}, \lambda w_{0}, \lambda B\right): j=1,2,3,4\right\}$. In all cases it is understood that the stochastic structure

\footnotetext{
Al Note two differences in the notation relative to that in the main text. First, the RRA coefficient is denoted by $1-\gamma$ rather than by $\alpha$. Second, the number of consol bonds is $b$ (rather than 1 ) and the interest per bond is 1 (rather than b).
} 
remains unchanged (i.e., no change in the $\Pi_{j k}$ 's $j=1,2,3,4, k=1,2,3,4$ ).

The equations defining equilibrium in the above lemma assume that the bonds are perpetuities, paying one unit of consumption every period. An identical argument holds if the bonds are one-period discount bonds paying one unit of consumption one period after issuance only.

Theorem A.1: Let the period utility function $u(c)$ be of the form $u(c)=c / \gamma, \gamma<0$, and consider an economy defined by $\left\{\left(y_{j}, w_{j}^{1}, w_{0}, B\right): j=1,2,3,4\right\}$ with $B>0, w_{j}^{1}>0, j=1,2,3,4$, and $d_{j}^{e}>0, j=1,2,3,4$. Then a constrained equilibrium exists for this economy.

Proof: Let $\hat{\lambda}$ be defined by

$$
\begin{aligned}
& \hat{\lambda}=\frac{1}{2} \min \left\{\frac{1}{y_{j}}: j=1,2,3,4\right\} . \text { Thus, } \\
& \hat{\lambda} \leq \frac{1}{2}\left(\frac{1}{y_{j}}\right), j=1,2,3,4, \text { or } \hat{\lambda} y_{j} \leq \frac{1}{2}<1, j=1,2,3,4 .
\end{aligned}
$$

We will prove the existence of equilibrium for the economy $\left\{\left(\hat{\lambda} y_{j}, \hat{\lambda} w_{j}^{1}, \hat{\lambda} w_{0}, \hat{\lambda} B\right): j=1,2,3,4\right\}$, knowing, by the lemma, that an equilibrium will also exist for the original economy as well. For simplicity, let us make the following identification: $\hat{y}_{j}=\hat{\lambda} y_{j}, \hat{w}_{j}^{1}=\hat{\lambda} w_{j}^{1}, \hat{w}_{0}=\hat{\lambda} w_{0}$, and $\hat{B}=\hat{\lambda} B$, with $\hat{d}_{j}^{e}=\hat{y}_{j}-\hat{w}_{j}^{1}-\hat{w}_{0}-B>0$.

The following properties of the scaled economy will be used in the argument:

(i) $\quad \hat{w}_{j}^{1}<1$, since $\hat{w}_{j}^{1} \leq y_{j}<1$, for all $j$ 's ;

(ii) $\hat{B}>0$, since $B>0$, by assumption;

(iii) $\quad \hat{d}_{j}^{e}>0$, since $d_{j}^{e}>0$, by assumption; and

(iv) $\beta\left(\hat{d}_{j}^{e}+B\right)^{r}<1$, since $\beta<1$, and $\hat{d}_{j}^{e}+\hat{B}<\hat{y}_{j}<1$.

Define $A_{j}=\left\{\left(q_{j}^{e}, q_{j}^{b}\right): q_{j}^{e} \geq 0, q_{j}^{b} \geq 0\right.$, and $\left.q_{j}^{e}+\hat{B} q_{j}^{b} \leq \hat{w}_{j}^{1}\right\}$ for $j=1,2,3,4$. $A_{\mathrm{j}}$ is both compact and convex. So also is the Set $A$, where $A=A_{1} \times A_{2} \times A_{3} \times A_{4}$. Define a mapping $F_{1}$ on $A$, by $F\left(\left(q_{1}^{e}, q_{1}^{b}\right),\left(q_{2}^{e}, q_{2}^{b}\right),\left(q_{3}^{e}, q_{3}^{b}\right),\left(q_{4}^{e}, q_{4}^{b}\right)\right)=\left(\left(\widetilde{q}_{1}^{e}, \widetilde{q}_{1}^{b}\right),\left(\widetilde{q}_{2}^{e}, \widetilde{q}_{2}^{b}\right),\left(\widetilde{q}_{3}^{e}, \widetilde{q}_{3}^{b}\right),\left(\widetilde{q}_{4}^{e}, \widetilde{q}_{4}^{b}\right)\right)$, where 
(iii)

$$
\widetilde{q}_{j}^{c}=\beta \sum_{k=1}^{4} \frac{\left(q_{k}^{e}+\hat{d}_{k}^{e}\right)\left(\hat{w}_{j}^{1}-q_{j}^{e}-q_{j}^{b} \hat{B}\right)^{1-\gamma} \Pi_{j k}}{\left(\left[q_{k}^{e}+\hat{d}_{k}^{e}\right]+\left[q_{k}^{b}+1\right] \hat{B}\right)^{1-\gamma}}
$$

and

$$
\widetilde{q}_{j}^{h}=\beta \sum_{k=1}^{4} \frac{\left(q_{k}^{b}+\hat{d}_{k}^{e}\right)\left(\hat{w}_{j}^{1}-q_{j}^{e}-q_{j}^{b} \hat{B}\right)^{1-\gamma} \Pi_{j k}}{\left(\left[q_{k}^{e}+\hat{d}_{k}^{e}\right]+\left[q_{k}^{b}+1\right] \hat{B}\right)^{1-\gamma}}
$$

Note that a fixed point of $F$ is an equilibrium for the economy $\left\{\hat{y}_{j}, \hat{w}_{j}^{1}, \hat{w}^{0}, \hat{B}\right\}$ provided it lies in $A$. Clearly $F$ is continuous, as the right hand side of equations (iii) and (iv) are ratios of continuous functions, with the denominator bounded away from zero. The latter assertion follows from the facts that $q_{k}^{e} \geq 0, q_{k}^{b} \geq 0 \forall \mathrm{k}$ and $\hat{d}_{k}^{e}+\hat{B}>0$. We thus need only demonstrate that $F: A \rightarrow A$, if we are to conclude, by Brower's Theorem that $F$ has a fixed point.

By construction $\tilde{q}_{j}^{e} \geq 0$ and $\tilde{q}_{j}^{b} \geq 0$; we need only demonstrate that $\tilde{q}_{j}^{e}+\hat{B} \tilde{q}_{j}^{b} \leq \hat{w}_{j}^{1}$ for all $j$.

$$
\begin{aligned}
& \widetilde{q}_{j}^{e}+\hat{B} \widetilde{q}_{j}^{b}=\beta \sum_{k=1}^{4} \frac{\left(q_{k}^{e}+\hat{d}_{k}^{e}\right)\left(\hat{w}_{j}^{1}-q_{j}^{e}-q_{j}^{b} \hat{B}\right)^{1-\gamma} \Pi_{j k}}{\left(\left[q_{k}^{e}+\hat{d}_{k}^{e}\right]+\left[q_{k}^{b}+1\right] \hat{B}\right)^{1-\gamma}}+\frac{\hat{B}\left(q_{k}^{b}+1\right)\left(\hat{w}_{j}^{1}-q_{j}^{e}-q_{j}^{b} \hat{B}\right)^{1-\gamma} \Pi_{j k}}{\left(\left[q_{k}^{e}+\hat{d}_{k}^{e}\right]+\left[q_{k}^{b}+1\right] \hat{B}\right)^{1-\gamma}} \\
& =\left(\hat{w}_{j}^{1}-q_{j}^{e}-q_{j}^{b} \hat{B}\right)^{1-\gamma} \beta \sum_{k=1}^{4} \Pi_{j k}\left\{\frac{\left(q_{k}^{e}+\hat{d}_{k}^{e}\right)+\hat{B}\left(q_{k}^{b}+1\right)}{\left(\left[q_{k}^{e}+\hat{d}^{e} k\right]+\left[q_{k}^{b}+1\right] \hat{B}\right)^{1-\gamma}}\right\} \\
& =\left(\hat{w}_{j}^{1}-q_{j}^{e}-q_{j}^{b} \hat{B}\right)^{1-\gamma} \beta \sum_{k=1}^{4} \Pi_{j k}\left\{\frac{1}{\left(\left[q_{k}^{e}+\hat{d}_{k}^{e}\right]+\left[q_{k}^{b}+1\right] \hat{B}\right)^{-\gamma}}\right\} \\
& \leq\left(\hat{w}_{j}^{1}-q_{j}^{e}-q_{j}^{h} \hat{B}\right)^{1-\gamma} \sum_{k=1}^{4} \Pi_{j k} \frac{\beta}{\left(\hat{d}_{k}^{e}+\hat{B}\right)^{-\gamma}} \\
& \leq\left(\hat{w}_{i}^{1}-q_{j}^{e}-q_{j}^{l} \hat{B}\right)^{1-\gamma} \sum_{k=1}^{4} \Pi_{j k} \frac{\beta}{\left(\hat{d}_{k}^{e}+\hat{B}\right)^{-\gamma}} \leq\left(\hat{w}_{i}^{1}-q_{j}^{e}-q_{j}^{b} \hat{B}\right)^{1-\gamma} \sum_{k=1}^{4} \Pi_{j k} \\
& <\left(\hat{w}_{j}^{1}\right)^{1-\gamma}<\hat{w}_{j}^{1} \text { since } \hat{w}_{j}^{1}<1 \text { and } \gamma<0 \text {. }
\end{aligned}
$$

The borrowing constraint reduces the problem into a one-period optimization problem which is computed numerically using a standard Newton-Raphson algorithm. 


\section{APPENDIX B: Numerical Calculation of the Equilibrium}

In the unconstrained economy we begin with the domain of definition. We approximate the true functions $\mathrm{z}_{0}^{\mathrm{e}}\left(\mathrm{j}, \mathrm{z}_{-1}^{\mathrm{e}}, \mathrm{z}_{-1}^{\mathrm{b}}\right), \mathrm{z}_{0}^{\mathrm{b}}\left(\mathrm{j}, \mathrm{z}_{-1}^{\mathrm{e}}, \mathrm{z}_{-1}^{\mathrm{b}}\right), \mathrm{q}^{\mathrm{e}}\left(\mathrm{j}, \mathrm{z}_{-1}^{\mathrm{e}}, \mathrm{z}_{-1}^{\mathrm{b}}\right)$ and $\mathrm{q}^{\mathrm{b}}\left(\mathrm{j}, \mathrm{z}_{-1}^{\mathrm{e}}, \mathrm{z}_{-1}^{\mathrm{b}}\right)$ on a partition of the state space $\mathrm{G}$ where $\mathrm{G}=\{1,2,3,4\} \times \mathrm{G}_{\mathrm{Z}_{-1}^{\mathrm{e}}}^{\mathrm{e}} \times \mathrm{G}_{\mathrm{Z}_{-1}^{\mathrm{b}}}$. In the above set, $\mathrm{G}_{\mathrm{Z}_{-1}^{\mathrm{e}}}^{\mathrm{e}}$ and $\mathrm{G}_{\mathrm{Z}_{-1}^{\mathrm{b}}}^{\mathrm{b}}$ are sets of possible values of stocks and bonds carried over by the middle-aged agents.

Suppose we have a solution to the $(\mathrm{n}-1)$ st iterations:

$$
\left\{\begin{array}{l}
z_{0}^{\mathrm{e}}\left(j, z_{-1}^{\mathrm{e}}, \mathrm{z}_{-1}^{\mathrm{b}} ; \mathrm{n}-1\right) \\
\mathrm{z}_{0}^{\mathrm{b}}\left(\mathrm{j}, \mathrm{z}_{-1}^{\mathrm{e}}, \mathrm{z}_{-1}^{\mathrm{b}} ; \mathrm{n}-1\right) \\
\mathrm{q}^{\mathrm{e}}\left(\mathrm{j}, \mathrm{z}_{-1}^{\mathrm{e}}, \mathrm{z}_{-1}^{\mathrm{b}} ; \mathrm{n}-1\right) \\
\mathrm{q}^{\mathrm{b}}\left(\mathrm{j}, \mathrm{z}_{-1}^{\mathrm{e}}, \mathrm{z}_{-1}^{\mathrm{b}} ; \mathrm{n}-1\right)
\end{array}\right\}: \mathrm{G} \mapsto \mathrm{R}
$$

Then $\mathrm{z}_{0}^{\mathrm{e}}\left(\mathrm{j}, \mathrm{z}_{-1}^{\mathrm{e}}, \mathrm{z}_{-1}^{\mathrm{b}} ; \mathrm{n}\right), \mathrm{z}_{0}^{\mathrm{b}}\left(\mathrm{j}, \mathrm{z}_{-1}^{\mathrm{e}}, \mathrm{z}_{-1}^{\mathrm{b}} ; \mathrm{n}\right), \mathrm{q}^{\mathrm{e}}\left(\mathrm{j}, \mathrm{z}_{-1}^{\mathrm{e}}, \mathrm{z}_{-1}^{\mathrm{b}} ; \mathrm{n}\right)$ and $\mathrm{q}^{\mathrm{b}}\left(\mathrm{j}, \mathrm{z}_{-1}^{\mathrm{e}}, \mathrm{z}_{-1}^{\mathrm{b}} ; \mathrm{n}\right)$ are constructed as follows. Let the functions from the (n-1)st iteration be used to define the RHS of equations (i) - (iv) of the unconstrained equilibrium definition. The nth iteration functions then solve the following system of equations:

$$
\begin{aligned}
& \mathrm{u}_{1}\left(\mathrm{w}^{0}-\mathrm{q}^{\mathrm{e}}\left(\mathrm{j}, \mathrm{z}_{-1}^{\mathrm{e}}, \mathrm{z}_{-1}^{\mathrm{b}} ; \mathrm{n}\right) \mathrm{z}_{0}^{\mathrm{e}}\left(\mathrm{j}, \mathrm{z}_{-1}^{\mathrm{e}}, \mathrm{z}_{-1}^{\mathrm{b}} ; \mathrm{n}\right)-\mathrm{q}^{\mathrm{b}}\left(\mathrm{j}, \mathrm{z}_{-1}^{\mathrm{e}}, \mathrm{z}_{-1}^{\mathrm{b}} ; \mathrm{n}\right)\right. \\
& \left.\cdot z_{0}^{b}\left(j, z_{-1}^{e}, z_{-1}^{b} ; n\right)\right) q^{e}\left(j, z_{-1}^{e}, z_{-1}^{b} ; n\right) \\
& =\beta \sum_{\mathrm{k}=1}^{4} \mathrm{u}_{1}\left(\left[\mathrm{q}^{\mathrm{e}}\left(\mathrm{k}, \mathrm{z}_{0}^{\mathrm{e}}\left(\mathrm{j}, \mathrm{z}_{-1}^{\mathrm{e}}, \mathrm{z}_{-1}^{\mathrm{b}} ; \mathrm{n}\right), \mathrm{z}_{0}^{\mathrm{b}}\left(\mathrm{j}, \mathrm{z}_{-1}^{\mathrm{e}}, \mathrm{z}_{-1}^{\mathrm{b}} ; \mathrm{n}\right) ; \mathrm{n}-1\right)\right.\right. \\
& \left.+\mathrm{d}_{\mathrm{k}}^{\mathrm{e}}\right] \mathrm{z}_{0}^{\mathrm{e}}\left(\mathrm{k}, \mathrm{z}_{-1}^{\mathrm{e}}, \mathrm{z}_{-1}^{\mathrm{b}} ; \mathrm{n}\right)+\left[\mathrm { q } ^ { \mathrm { b } } \left(\mathrm{k}, \mathrm{z}_{0}^{\mathrm{e}}\left(\mathrm{j}, \mathrm{z}_{-1}^{\mathrm{e}}, \mathrm{z}_{-1}^{\mathrm{b}} ; \mathrm{n}\right),\right.\right. \\
& \left.\left.\mathrm{z}_{0}^{\mathrm{b}}\left(\mathrm{j}, \mathrm{z}_{-1}^{\mathrm{e}}, \mathrm{z}_{-1}^{\mathrm{b}} ; \mathrm{n}\right) ; \mathrm{n}-1\right)+1\right] \mathrm{z}_{0}^{\mathrm{b}}\left(\mathrm{j}, \mathrm{z}_{-1}^{\mathrm{e}}, \mathrm{z}_{-1}^{\mathrm{b}} ; \mathrm{n}\right) \\
& +w_{k}^{l}-q^{e}\left(k, z_{0}^{e}\left(j, z_{-1}^{e}, z_{-1}^{b} ; n\right), z_{0}^{b}\left(j, z_{-1}^{e}, z_{-1}^{b} ; n\right) ; n-1\right) \\
& \text { - } z_{1}^{\mathrm{e}}\left(\mathrm{k}, \mathrm{z}_{0}^{\mathrm{e}}\left(\mathrm{j}, \mathrm{z}_{-1}^{\mathrm{e}}, \mathrm{z}_{-1}^{\mathrm{b}} ; \mathrm{n}\right), \mathrm{z}_{0}^{\mathrm{b}}\left(\mathrm{j}, \mathrm{z}_{-1}^{\mathrm{e}}, \mathrm{z}_{-1}^{\mathrm{b}} ; \mathrm{n}\right) ; \mathrm{n}-1\right) \\
& -\mathrm{q}^{\mathrm{b}}\left(\mathrm{k}, \mathrm{z}_{0}^{\mathrm{e}}\left(\mathrm{j}, \mathrm{z}_{-1}^{\mathrm{e}}, \mathrm{z}_{-1}^{\mathrm{b}} ; \mathrm{n}\right), \mathrm{z}_{0}^{\mathrm{b}}\left(\mathrm{j}, \mathrm{z}_{-1}^{\mathrm{e}}, \mathrm{z}_{-1}^{\mathrm{b}} ; \mathrm{n}\right) ; \mathrm{n}-1\right) \\
& \text { - } \left.\mathrm{z}_{1}^{\mathrm{b}}\left(\mathrm{k}, \mathrm{z}_{0}^{\mathrm{e}}\left(\mathrm{j}, \mathrm{z}_{-1}^{\mathrm{e}}, \mathrm{z}_{-1}^{\mathrm{b}} ; \mathrm{n}\right), \mathrm{z}_{0}^{\mathrm{b}}\left(\mathrm{j}, \mathrm{z}_{-1}^{\mathrm{e}}, \mathrm{z}_{-1}^{\mathrm{b}} ; \mathrm{n}\right) ; \mathrm{n}-1\right)\right) \\
& \text { - }\left[\mathrm{q}^{\mathrm{e}}\left(\mathrm{k}, \mathrm{z}_{0}^{\mathrm{e}}\left(\mathrm{j}, \mathrm{z}_{-1}^{\mathrm{e}}, \mathrm{z}_{-1}^{\mathrm{b}} ; \mathrm{n}\right), \mathrm{z}_{0}^{\mathrm{b}}\left(\mathrm{j}, \mathrm{z}_{-1}^{\mathrm{e}}, \mathrm{z}_{-1}^{\mathrm{b}} ; \mathrm{n}\right) ; \mathrm{n}-1\right)+\mathrm{d}_{\mathrm{k}}^{\mathrm{e}}\right] \pi_{\mathrm{jh}}
\end{aligned}
$$

(ii) $\quad$ ul $_{1}$ (same argument as LHS of $\left.(\mathrm{i})^{\prime}\right) \mathrm{q}^{\mathrm{b}}\left(\mathrm{j}, \mathrm{z}_{-1}^{\mathrm{e}}, \mathrm{z}_{-1}^{\mathrm{b}} ; \mathrm{n}\right)$

$$
=\beta \sum_{k=1}^{4} u_{1}\left(\begin{array}{c}
\text { same argument as the } \\
\text { RHS of }(i)^{\prime}
\end{array}\right)
$$




$$
\bullet\left[\mathrm{q}^{\mathrm{b}}\left(\mathrm{k}, \mathrm{z}_{0}^{\mathrm{e}}\left(\mathrm{j}, \mathrm{z}_{-1}^{\mathrm{e}}, \mathrm{z}_{-1}^{\mathrm{b}} ; \mathrm{n}\right), \mathrm{z}_{0}^{\mathrm{b}}\left(\mathrm{j}, \mathrm{z}_{-1}^{\mathrm{e}}, \mathrm{z}_{-1}^{\mathrm{b}} ; \mathrm{n}\right) ; \mathrm{n}-1\right)+\mathrm{d}_{\mathrm{k}}^{\mathrm{e}}\right] \pi_{\mathrm{jh}}
$$

(iii)

$$
\begin{aligned}
& \mathrm{u}_{1}\left(\left[\mathrm{q}^{\mathrm{e}}\left(\mathrm{j}, \mathrm{z}_{-1}^{\mathrm{e}}, \mathrm{z}_{-1}^{\mathrm{b}} ; \mathrm{n}\right)+\mathrm{d}_{\mathrm{j}}^{\mathrm{e}}\right] \mathrm{z}_{-1}^{\mathrm{e}}+\left[\mathrm{q}^{\mathrm{b}}\left(\mathrm{j}, \mathrm{z}_{-1}^{\mathrm{e}}, \mathrm{z}_{-1}^{\mathrm{b}} ; \mathrm{n}\right)+1\right] \mathrm{z}_{-1}^{\mathrm{b}}\right. \\
& \quad-\mathrm{q}^{\mathrm{e}}\left(\mathrm{j}, \mathrm{z}_{-1}^{\mathrm{e}}, \mathrm{z}_{-1}^{\mathrm{b}} ; \mathrm{n}\right) \mathrm{z}_{1}^{\mathrm{e}}\left(\mathrm{j}, \mathrm{z}_{-1}^{\mathrm{e}}, \mathrm{z}_{-1}^{\mathrm{b}} ; \mathrm{n}\right) \\
& \left.\quad-\mathrm{q}^{\mathrm{b}}\left(\mathrm{j}, \mathrm{z}_{-1}^{\mathrm{e}}, \mathrm{z}_{-1}^{\mathrm{b}} ; \mathrm{n}\right) \mathrm{z}_{1}^{\mathrm{b}}\left(\mathrm{j}, \mathrm{z}_{-1}^{\mathrm{e}}, \mathrm{z}_{-1}^{\mathrm{b}} ; \mathrm{n}\right)\right) \mathrm{q}^{\mathrm{e}}\left(\mathrm{j}, \mathrm{z}_{-1}^{\mathrm{e}}, \mathrm{z}_{-1}^{\mathrm{b}} ; \mathrm{n}\right)
\end{aligned}
$$

$$
=\beta \sum_{\mathrm{k}=1}^{4} \mathrm{u}_{1}\left(\left[\mathrm{q}^{\mathrm{e}}\left(\mathrm{k}, \mathrm{z}_{0}^{\mathrm{e}}\left(\mathrm{j}, \mathrm{z}_{-1}^{\mathrm{e}}, \mathrm{z}_{-1}^{\mathrm{b}} ; \mathrm{n}\right) \mathrm{z}_{0}^{\mathrm{b}}\left(\mathrm{j}, \mathrm{z}_{-1}^{\mathrm{e}}, \mathrm{z}_{-1}^{\mathrm{b}} ; \mathrm{n}\right) ; \mathrm{n}-1\right)+\mathrm{d}_{\mathrm{k}}^{\mathrm{e}}\right]\right.
$$

$\cdot \mathrm{z}_{1}^{\mathrm{e}}\left(\mathrm{j}, \mathrm{z}_{-\mathrm{j}}^{\mathrm{e}}, \mathrm{z}_{-1}^{\mathrm{b}} ; \mathrm{n}\right)$

$$
\begin{aligned}
+\left[q^{b}\left(k, z_{0}^{e}\left(j, z_{-1}^{e}, z_{-1}^{b} ; n\right), z_{0}^{b}\left(j, z_{-1}^{e}, z_{-1}^{b} ; n\right) ; n-1\right)+1\right] \\
\left.\cdot z_{1}^{b}\left(j, z_{-1}^{e}, z_{-1}^{b} ; n\right)\right)
\end{aligned}
$$

$\cdot\left[q^{\mathrm{e}}\left(k, z_{0}^{\mathrm{e}}\left(j, z_{-1}^{\mathrm{e}}, \mathrm{z}_{-1}^{\mathrm{b}} ; \mathrm{n}\right), \mathrm{z}_{0}^{\mathrm{b}}\left(\mathrm{j}, \mathrm{z}_{-1}^{\mathrm{e}}, \mathrm{z}_{-1}^{\mathrm{b}} ; \mathrm{n}\right) ; \mathrm{n}-1\right)+\mathrm{d}_{\mathrm{h}}^{\mathrm{e}}\right] \pi_{\mathrm{jh}}$

(iv) $\quad \mathrm{u}_{1}\left(\begin{array}{c}\text { same argument as in } \\ \text { LHS of (iii) }\end{array}\right) \mathrm{q}^{\mathrm{b}}\left(\mathrm{j}, \mathrm{z}_{-1}^{\mathrm{e}}, \mathrm{z}_{-1}^{\mathrm{b}} ; \mathrm{n}\right)$

$$
=\beta \sum_{\mathrm{k}=1}^{4} \mathrm{u}_{1}\left(\begin{array}{c}
\text { same argument as in } \\
\text { LHS of (iii) }
\end{array}\right)\left[\mathrm { q } ^ { \mathrm { b } } \left(\mathrm{k}, \mathrm{z}_{0}^{\mathrm{e}}\left(\mathrm{j}, \mathrm{z}_{-1}^{\mathrm{e}}, \mathrm{z}_{-1}^{\mathrm{b}} ; \mathrm{n}\right)\right.\right.
$$

$$
\left.\left.z_{0}^{b}\left(j, z_{-1}^{e}, z_{-1}^{e} ; n\right) ; n-1\right)+1\right] \pi_{j h}
$$

$(v)^{\prime} z_{1}^{e}\left(j, z_{-1}^{e}, z_{-1}^{b} ; n\right)=1-z_{0}^{e}\left(j, z_{-1}^{e}, z_{-1}^{b} ; n\right)$

(vi) $\quad z_{1}^{b}\left(j, z_{-1}^{e}, z_{-1}^{b} ; n\right)=b-z_{0}^{b}\left(j, z_{-1}^{e}, z_{-1}^{b} ; n\right)$

Interpolation: Note that in the above set of optimality equations (RHS) we encounter expression of the form: $\mathrm{q}^{\mathrm{e}}\left(\mathrm{k}, \mathrm{z}_{0}^{\mathrm{e}}\left(\mathrm{j}, \mathrm{z}_{-1}^{\mathrm{e}}, \mathrm{z}_{-1}^{\mathrm{b}} ; \mathrm{n}\right), \mathrm{z}_{0}^{\mathrm{b}}\left(\mathrm{j}, \mathrm{z}_{-1}^{\mathrm{e}}, \mathrm{z}_{-1}^{\mathrm{b}} ; \mathrm{n}\right) ; \mathrm{n}-1\right), \mathrm{q}^{\mathrm{b}}\left(\mathrm{k}, \mathrm{z}_{0}^{\mathrm{e}}\left(\mathrm{j}, \mathrm{z}_{-1}^{\mathrm{e}}, \mathrm{z}_{-1}^{\mathrm{b}} ; \mathrm{n}\right), \mathrm{z}_{0}^{\mathrm{b}}\left(\mathrm{j}, \mathrm{z}_{-1}^{\mathrm{e}}, \mathrm{z}_{-1}^{\mathrm{b}} ; \mathrm{n}\right)\right.$; $n-1), z_{1}^{e}\left(k, z_{0}^{e}\left(j, z_{-1}^{e}, z_{-1}^{b} ; n\right), z_{0}^{b}\left(j, z_{-1}^{e}, z_{-1}^{b} ; n\right), n-1\right)$ and $z_{1}^{b}\left(k, z_{0}^{e}\left(j, z_{-1}^{e}, z_{-1}^{b} ; n\right), z_{0}^{b}\left(j, z_{-1}^{e}, z_{-1}^{b} ; n\right)\right.$, 11-1). It needs to be explained how these functions are defined if the solution functions $z_{0}^{\mathrm{e}}\left(\mathrm{j}, \mathrm{z}_{-1}^{\mathrm{e}}, \mathrm{z}_{-1}^{\mathrm{b}} ; \mathrm{n}\right)$ and $z_{0}^{b}\left(j, z_{-1}^{c}, z_{-1}^{b} ; n\right)$ do not lie on elements of $G_{Z_{-1}^{e}}^{e} \times G_{Z_{-1}}^{b}$. This is accomplished as follows: Let $\Delta_{z^{i},}$ be the norm of the partition $G_{z_{-1}^{e}}$ and let $\Delta_{z_{-1}^{b}}$ be the norm of the $G_{z_{-1}^{b}}$ partition. Suppose it was 
necessary to evaluate $\mathrm{q}^{\mathrm{e}}(\mathrm{k}, \cdot, ; \mathrm{n}-1)$ at values of $\mathrm{z}_{0}^{\mathrm{e}}\left(\mathrm{j}, \mathrm{z}_{-1}^{\mathrm{e}}, \mathrm{z}_{-1}^{\mathrm{b}} ; \mathrm{n}\right)$, and $\mathrm{z}_{0}^{\mathrm{b}}\left(\mathrm{j}, \mathrm{z}_{-1}^{\mathrm{e}}, \mathrm{z}_{-1}^{\mathrm{b}} ; \mathrm{n}\right)$, for which

$$
\begin{aligned}
& \mathrm{z}_{0}^{\mathrm{e}}\left(\mathrm{j}, \mathrm{z}_{-1}^{\mathrm{e}}, \mathrm{z}_{-1}^{\mathrm{b}} ; \mathrm{n}\right),=\mathrm{z}_{0}^{\mathrm{e}}(\mathrm{m})+\gamma_{\mathrm{e}} \Delta_{\mathrm{z}_{-1}^{\mathrm{c}}} \text {, and } \\
& \mathrm{z}_{0}^{\mathrm{b}}\left(\mathrm{j}, \mathrm{z}_{-1}^{\mathrm{e}}, \mathrm{z}_{-1}^{\mathrm{b}} ; \mathrm{n}\right),=\mathrm{z}_{0}^{\mathrm{b}}(\ell)+\gamma_{\mathrm{b}} \Delta_{\mathrm{z}_{-1}^{\mathrm{b}}} \text {, where } \\
& \mathrm{z}_{0}^{\mathrm{e}}(\mathrm{m}) \in \mathrm{G}_{\mathrm{Z}_{-1}^{\mathrm{e}}}^{\mathrm{e}} \quad \text { (i.e., the mth grid point), } \\
& \mathrm{z}_{0}^{\mathrm{b}}(\mathrm{l}) \in \mathrm{G}_{\mathrm{Z}_{-1}^{\mathrm{b}}}^{\mathrm{b}} \quad \text { (i.e., the } 1 \text { th grid point), and } \\
& 0<\gamma_{\mathrm{e}}<1,0<\gamma_{\mathrm{b}}<1 .
\end{aligned}
$$

In this case, for example, the $\mathrm{q}^{\mathrm{e}}(\cdot, \cdot, \cdot ; \mathrm{n})$ function is defined according to:

$q^{e}\left(k, z_{0}^{e}\left(j, z_{-1}^{e}, z_{-1}^{e} ; n\right), z_{0}^{b}\left(j, z_{-1}^{e}, z_{-1}^{e} ; n\right) ; n-1\right)$

$$
\begin{aligned}
& =\left(1-\gamma_{\mathrm{e}}\right)\left(1-\gamma_{\mathrm{b}}\right) \mathrm{q}^{\mathrm{e}}\left(\mathrm{k}, \mathrm{z}_{0}^{\mathrm{e}}(\mathrm{m}), \mathrm{z}_{0}^{\mathrm{b}}(\mathrm{l}) ; \mathrm{n}-1\right) \\
& +\left(1-\gamma_{\mathrm{e}}\right)\left(\gamma_{\mathrm{b}}\right) \mathrm{q}^{\mathrm{e}}\left(\mathrm{k}, \mathrm{z}_{0}^{\mathrm{e}}(\mathrm{m}), \mathrm{z}_{0}^{\mathrm{b}}(1+1) ; \mathrm{n}-1\right) \\
& +\gamma_{\mathrm{e}}\left(1-\gamma_{\mathrm{b}}\right) \mathrm{q}^{\mathrm{e}}\left(\mathrm{k}, \mathrm{z}_{0}^{\mathrm{e}}(\mathrm{m}+1), \mathrm{z}_{0}^{\mathrm{b}}(\mathrm{l}) ; \mathrm{n}-1\right) \\
& +\gamma_{\mathrm{e}} \gamma_{\mathrm{b}} \mathrm{q}^{\mathrm{e}}\left(\mathrm{k}, \mathrm{z}_{0}^{\mathrm{e}}(\mathrm{m}+1), \mathrm{z}_{0}^{\mathrm{e}}(1+1) ; \mathrm{n}-1\right)
\end{aligned}
$$

The remaining functions are constructed analogously. A Newton-Raphson algorithm is used to construct the nth iterative solution, given the above approximation. Our experience has been that not less than 500 iterations are required for convergence. For the constrained problem the equilibrium is solved for directly again using a Newton-Raphson algorithm. 